\title{
Ice-Flow Chronology and Palimpsest, Long-Distance Dispersal of Indicator Clasts, North of the St. Lawrence River Valley, Quebec
}

\section{Séquence d'écoulements glaciaires et dispersion lointaine d'erratiques distinctifs au nord de la vallée du Saint-Laurent, Québec}

\author{
Jean J. Veillette
}

Volume 58, numéro 2-3, 2004

Glacial History, Paleogeography and Paleoenvironments in Glaciated North America

URI : https://id.erudit.org/iderudit/013138ar

DOI : https://doi.org/10.7202/013138ar

Aller au sommaire du numéro

Éditeur(s)

Les Presses de l'Université de Montréal

ISSN

0705-7199 (imprimé)

1492-143X (numérique)

Découvrir la revue

Citer cet article

Veillette, J. J. (2004). Ice-Flow Chronology and Palimpsest, Long-Distance Dispersal of Indicator Clasts, North of the St. Lawrence River Valley, Quebec. Géographie physique et Quaternaire, 58(2-3), 187-216.

https://doi.org/10.7202/013138ar

\section{Résumé de l'article}

Une séquence d'écoulements glaciaires est proposée pour expliquer l'évolution d'une grande partie du secteur du Labrador de la calotte laurentidienne au cours du Wisconsinien, à partir de la répartition d'erratiques distinctifs provenant des roches protérozoïques des bassins sédimentaires du lac Mistassini et des monts Otish, et de celle de stries glaciaires anciennes dans une région d'environ $230000 \mathrm{~km}^{2}$, dont la majeure partie est située dans la province de Grenville, au Québec. Ces nouvelles données ont été ajoutées à celles provenant de levés semblables menés antérieurement en Abitibi, et plus loin au nord. Les surfaces striées et les indicateurs lithologiques de transport glaciaire, associés au premier écoulement vers le nord-ouest, recoupés par ceux d'un écoulement majeur vers le sud-est, et ensuite par ceux d'écoulements vers le sud-ouest, le sud et le sud-est, lors de la déglaciation du territoire, témoignent d'une suite complexe d'évènements glaciaires. Le mouvement initial, vers le nord-ouest, résulte d'une zone de partage des glaces d'orientation NE-SO, située dans les hautes terres du Québec, au sud du lac Mistassini, laquelle se déplaça au nord du lac Mistassini au Pléniglaciaire, pour former l'écoulement vers le sud-est, dont les traces couvrent une grande partie de la province de Grenville. Lors de la dernière déglaciation des ajustements dans le sens d'écoulement des glaces ont engendré des rotations dans le sens horaire au sud du lac Mistassini, et contraire au sens horaire au nord de celui-ci. La coalescence de centres d'englacement au Wisconsinien inférieur, à partir de glaciers isolés sur les plus hauts sommets, le long d'une zone située au nord et parallèle au Saint-Laurent, aurait formé le lieu initial de partage des glaces d'orientation NE-SO; l'expansion de ce glacier vers le nord-ouest est attribué à l'accumulation préférentielle de glace sur ce coté du glacier, exposé aux vents dominants (windward growth). Ce modèle d'écoulements glaciaires est d'intérêt pour l'exploration minérale fondée sur l'analyse des dépôts glaciaires. 


\title{
ICE-FLOW CHRONOLOGY AND PALIMPSEST, LONG-DISTANCE DISPERSAL OF INDICATOR CLASTS, NORTH OF THE ST. LAWRENCE RIVER VALLEY, QUEBEC
}

\author{
Jean J. VEILLETTE*, Geological Survey of Canada, 601 Booth Street, Ottawa, Ontario K1A OE8.
}

\begin{abstract}
An ice flow model, based on the distribution of distinctive Proterozoic erratics from the Lake Mistassini and Monts Otish sedimentary basins, and on the mapping of relict striations in a $230000 \mathrm{~km}^{2}$ area located predominantly in Grenville Province, Québec, is presented to reconstruct the evolution of a large part of the Labrador Sector of the Laurentide Ice Sheet during the Wisconsinan. The results, were added to those of similar surveys carried out in the Abitibi region, and further north. Striated surfaces and indicator clasts from an early northwestward flow, overprinted by those from a widespread southeastward flow, and lastly by those from deglaciation flows toward the southwest, south, and southeast, revealed a complex sequence of events. The northwestward flow originated from a NE-SW, early Wisconsinan, ice divide located in the Québec highlands, south of Lake Mistassini, that migrated to a position north of the lake, at the Last Glacial Maximum, to give rise to the widespread, southeastward ice flow, that left traces over a large part of Grenville Province. Deglaciation triggered a clockwise shift in ice-flow south of Lake Mistassini, and a counterclockwise shift, north of it. Inception of the northwestward flowing glacier probably results from the coalescence of ice caps formed at the highest elevations along a narrow fringe, north of and parallel to the St. Lawrence River Valley, and expansion toward the northwest suggests a similarity with the windward growth model of ice sheet expansion. The ice flow model has implications for mineral exploration methods based on the sampling of glacial sediments.
\end{abstract}

RÉSUMÉ Séquence d'écoulements glaciaires et dispersion lointaine d'erratiques distinctifs au nord de la vallée du Saint-Laurent, Québec. Une séquence d'écoulements glaciaires est proposée pour expliquer l'évolution d'une grande partie du secteur du Labrador de la calotte laurentidienne au cours du Wisconsinien, à partir de la répartition d'erratiques distinctifs provenant des roches protérozoïques des bassins sédimentaires du lac Mistassini et des monts Otish, et de celle de stries glaciaires anciennes dans une région d'environ $230000 \mathrm{~km}^{2}$, dont la majeure partie est située dans la province de Grenville, au Québec. Ces nouvelles données ont été ajoutées à celles provenant de levés semblables menés antérieurement en Abitibi, et plus loin au nord. Les surfaces striées et les indicateurs lithologiques de transport glaciaire, associés au premier écoulement vers le nord-ouest, recoupés par ceux d'un écoulement majeur vers le sud-est, et ensuite par ceux d'écoulements vers le sud-ouest, le sud et le sud-est, lors de la déglaciation du territoire, témoignent d'une suite complexe d'évènements glaciaires. Le mouvement initial, vers le nord-ouest, résulte d'une zone de partage des glaces d'orientation NE-SO, située dans les hautes terres du Québec, au sud du lac Mistassini, laquelle se déplaça au nord du lac Mistassini au Pléniglaciaire, pour former l'écoulement vers le sud-est, dont les traces couvrent une grande partie de la province de Grenville. Lors de la dernière déglaciation des ajustements dans le sens d'écoulement des glaces ont engendré des rotations dans le sens horaire au sud du lac Mistassini, et contraire au sens horaire au nord de celui-ci. La coalescence de centres d'englacement au Wisconsinien inférieur, à partir de glaciers isolés sur les plus hauts sommets, le long d'une zone située au nord et parallèle au Saint-Laurent, aurait formé le lieu initial de partage des glaces d'orientation NE-SO; l'expansion de ce glacier vers le nord-ouest est attribué à l'accumulation préférentielle de glace sur ce coté du glacier, exposé aux vents dominants (windward growth). Ce modèle d'écoulements glaciaires est d'intérêt pour l'exploration minérale fondée sur l'analyse des dépôts glaciaires.

Manuscrit reçu le 11 juillet 2005 ; manuscrit révisé accepté le 8 février 2006 (publié le $2^{e}$ trimestre 2006)

*E-mail address: jveillet@nrcan.gc.ca 


\section{INTRODUCTION}

The reconstruction of the sequence of events that occurred throughout the Wisconsinan on the Canadian Shield must rely almost exclusively on surface ice-flow and glacial transport data. Natural sections exposing non-glacial sediments, overlain by till and/or glaciofluvial deposits, are extremely rare. Broad, regional ice flow studies, over large areas of the Canadian Shield, have largely been limited to the mapping of apparent glacial lineaments from satellite imagery or conventional airphotos, with little control from striations and glacial transport data (Boulton and Clark, 1990; Clark et al., 2000; Jansson et al., 2002). For the eastern part of the Laurentide Ice Sheet (LIS) complex sequences of shifting ice flows were proposed, particularly in Témiscamingue, Abitibi, southwest of Hudson Bay, in Labrador, to the east and to the northwest of Hudson Bay, using the dispersal of distinctive clasts or geochemical indicators, the striation record and the orientation of landforms (Veillette, 1986; Veillette and McClenaghan, 1996; Thorleifson et al., 1992; Klassen and Thompson, 1993; Parent et al., 1996; Veillette et al., 1999; McMartin and Henderson, this volume). Most detailed ice-flow reconstructions, however, have been confined to the geological provinces with the highest mineral potential. As a result, the Grenville Province, which occupies about a third of Québec, was largely neglected by Quaternary scientists in favour of the Superior Province to the north, where mining is an important sector of the economy.

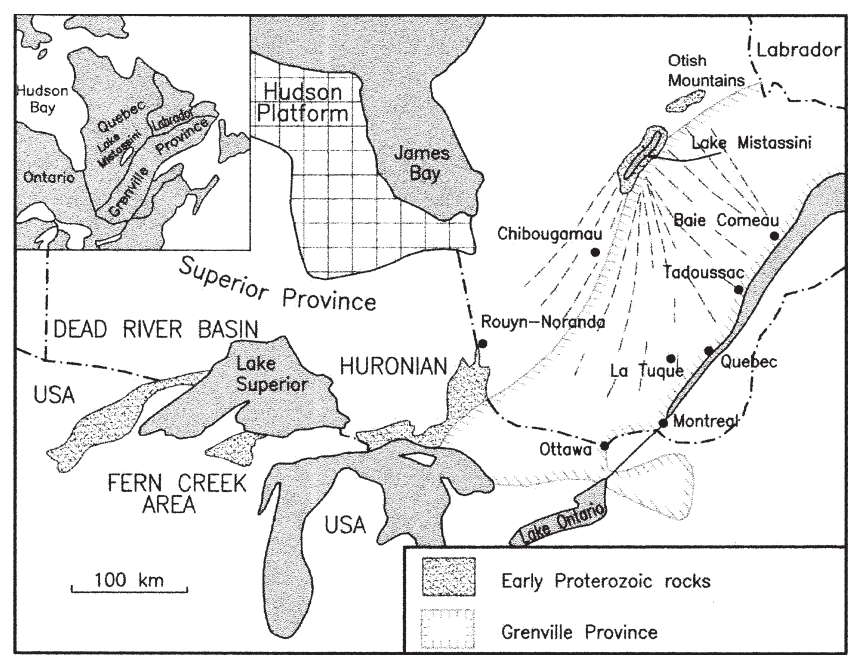

FIGURE 1. Location of the Lake Mistassini Proterozoic rocks in relation to other areas of Early Proterozoic rocks (Dead River basin, Fern Creek and Huronian areas) found along the southern edge of the Superior craton (adapted from Young, 1970). The southward dispersal area of Mistassini erratics (dashed lines) covers about half of the Grenville Province in Québec.

Localisation des roches protérozoiques de la région du lac Mistassini et autres îlots de roches du Protérozoique inférieur (bassin de la Dead River, du ruisseau Fern et des roches Huronniennes) situés le long de la marge sud de la Province du Supérieur (adapté de Young, 1970). La dispersion vers le sud (en tiretés) couvre environ la moitié de la Province de Grenville au Québec.
This study (Fig. 1) presents new ice-flow and glacial transport data for a large area of Grenville Province where this type of information had never been systematically recorded. It is the continuation of earlier work (Veillette et al., 1999), carried out in a large part of the eastern Hudson Bay basin, where iceflow indicators of a widespread, former, northwestward ice flow, were mapped as far south as the Chibougamau area. The objectives were (1) to map the maximum distances of transport of surface, indicator clasts from the Proterozoic rocks of the Mistassini basin carried by the last ice flow (flows), and by former ice flows revealed by relict striations indicative of ice movement in directions different from that of the last flow (flows), (2) to correlate the results with the striation record obtained during this study and from earlier studies to the north, (3) to verify the sequence of shifting ice flows proposed for the Grenville Province by Veillette et al., (1999), on the basis of rare ice flow data for this part of the LIS, (4) to assist mineral exploration based on methods applicable in glaciated terrain.

Because of their distinctive visual characteristics, erratics from the Proterozoic sedimentary rocks of the ChibougamauLake Mistassini-Otish Mountains area (collectively referred to in this paper as Mistassini erratics unless specified otherwise), constitute exceptional lithological indicators of glacial transport, readily identified in the field, in the predominantly granitic and gneissic drift cover of Grenville Province. The source rocks, when viewed at a continental scale, approximate a point source. Their position in the central part of the Labrador Sector (LS) of the LIS, and their proximity to a major demarcation zone separating opposing former ice flows, toward Hudson Bay, and toward the St. Lawrence River Valley, are ideally located to map changes in ice-flow directions over time. The search for the erratics was carried out over several years in about half the area underlain by Grenville Province in Québec (Fig. 2). They constitute long-distance (up to $550 \mathrm{~km}$ ) transport indicators that were distributed by a sequence of ice flows revealed by the relative chronology of striated bifaceted or multifaceted rock outcrops. The new data support the windward growth model of expansion for the LIS (Flint, 1943).

\section{STUDY AREA}

Within the $230000 \mathrm{~km}^{2}$ area (Fig. 2), Mistassini erratics were searched for in selected borrow pits and road cuts, along about $4000 \mathrm{~km}$ of roads by truck, and along $3000 \mathrm{~km}$ of lake and reservoir shorelines by boat. The search was conducted in periods of low water level, during late summer and fall from 1997 to 2003, on all large water bodies shown on Figure 2, except lakes Saint-Jean, Assinica, Frotet and Chibougamau, and the Manic-Deux and Peribonka reservoirs. Names and areas of water surface of lakes and reservoirs cited in the text are from the Commission de toponymie du Québec (1996). Ice-flow and glacial transport data are from the Geological Survey of Canada surficial geology mapping programs in Témiscamingue, Abitibi, and Chibougamau areas, from unpublished regional studies carried out by the author in the Lake Evans area, and from Ressources naturelles du Québec and graduate students (M.Sc. thesis) in the ChibougamauLake Mistassini area (Fig. 2). 


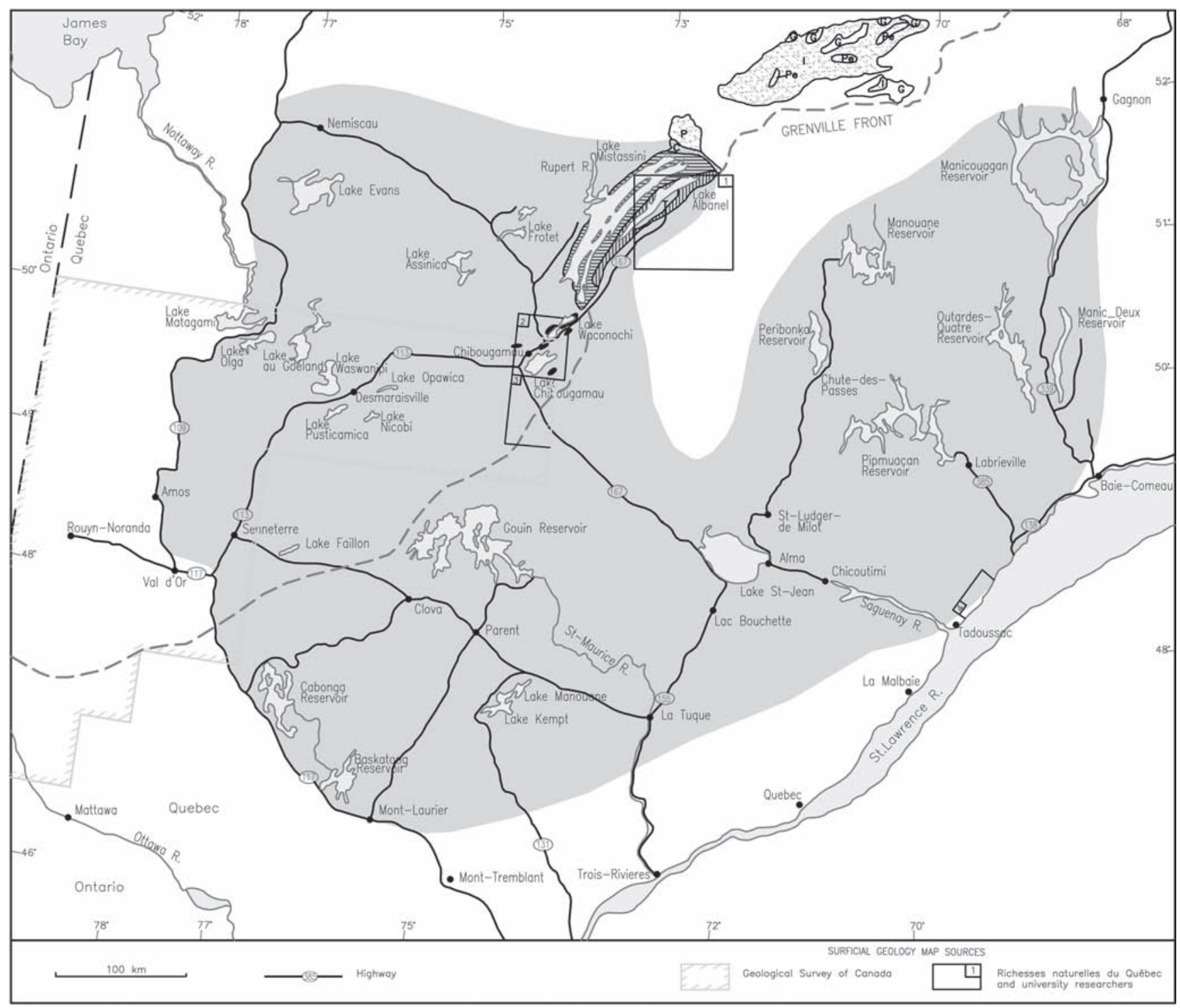

FIGURE 2. Area searched for Mistassini erratics (shaded) along roads, and along lake and reservoir shorelines. Except for Lake Saint-Jean, and the Manic-Deux and Peribonka reservoirs, shorelines of all large water bodies were examined. Ice-flow and glacial transport data were compiled from surficial geology maps published by the Geological Survey of Canada (Veillette, 1996; Veillette et al., 2003; Paradis, 2003a, 2003b, 2003c, 2003d), by Ressources naturelles du Québec, by university graduate students, Dilabio (1976), south end of Lake Mistassini, Block 1 (Bouchard, 1980; Bouchard et al., 1984; Cadieux, 1986), Block 2 (Martineau, 1984; Martineau et al., 1984; Prichonnet et al., 1984), Block 3 (De Corta, 1988), Block 4 (Dionne, 1986, 1994), and from unpublished results by the author in Lake Evans-Nemiscau area. See Figure 5 for the description of the geology of the source rocks.

\section{PREVIOUS WORK}

Observations on the transport of glacial erratics and on the orientation of striations led Agassiz (1840) to propose the glacial theory. Since then glacial transport was used by many others (e.g. Sauramo, 1929; Flint, 1971; Boulton et al., 1985) to reconstruct the dynamics of continental ice sheets. Krumbein
Territoire couvert par les levés d'erratiques du Mistassini (ombragé), le long des routes et des rivages de lacs et de réservoirs. Tous les grands plans d'eau montrés sur la carte ont été visités à l'exception du lac Saint-Jean et des réservoirs de Manic-Deux et de Péribonka. Des données d'écoulement de transport glaciaire proviennent des cartes de formation en surface de la Commission géologique du Canada (Veillette, 1996; Veillette et al., 2003; Paradis, 2003a, 2003b, 2003c, 2003d), des Ressources naturelles du Québec, et de travaux d'étudiants, Dilabio (1976), dans la partie sud du lac Mistassini, Bloc 1 (Bouchard, 1980; Bouchard et al., 1984; Cadieux, 1986), Bloc 2 (Martineau, 1984; Martineau et al., 1984; Prichonnet et al., 1984), Bloc 3 (De Corta, 1988), Bloc 4 (Dionne, 1986, 1994), et de travaux inédits par l'auteur dans la région du lac Evans et de Nemiscau. Voir la figure 5 pour la description de la géologie des roches sources.

(1937) showed that debris entrained in glaciers reach a peak close to its source, followed by an exponential decline downice. He expressed this condition graphically as the half-distance value, that is the distance in the direction of ice movement from the distal contact of an indicator rock, to a point where the frequency of indicator clasts reach $50 \%$. One of the better-known studies of erratic distribution was by Salonen 
(1986) who studied the distribution of surface boulders over the whole of Finland to estimate average glacial transport distances. In North America, Shilts (1976) described clast abundance profiles in terms of a "head" located immediately downice from the distal contact, in which the abundance decreases exponentially, and a "tail" in which the decrease is linear. Mapping the distribution of far-traveled erratics, from known source areas, has been fundamental to infer directions of movement and shifts of the ice mass through time (Prest and Nielsen, 1987; Kaszycki, 1989). The analysis of long-distance transport of Precambrian Shield indicator clasts in till, from a source in southern Ontario, Canada, to large ice-marginal moraines in Ohio and Indiana, U.S.A., led Strobel and Faure (1987) to conclude that the abundance of the clasts $(100 \%$ at the source) decreases exponentially but then remains nearly constant (4\%) for more than $800 \mathrm{~km}$ down-ice.

In spite of extensive traveling along rivers reaching Lake Mistassini from the southeast, the southwest, and the north, Low (1886) did not report erratics from the Lake Mistassini basin rocks (which he referred to as Cambrian limestones) at great distances from the lake. He noted, however, that no erratics from these rocks were found to the northwest (along Rupert River) and to the east of the lake, a situation he attributed to the widespread southwestward ice flow. More than half a century later, isolated striations indicative of an older southeastward ice flow crossed by striations from a younger southwestward flow were reported in the general area around Lake Mistassini (Ignatius, 1958; Gillett, 1966; Murphy, 1966). Dilabio (1976: p. 44) measured some till fabrics that may indicate flow toward the east. Evidence for the former southeastward ice flow, provided by cross-striations and glacial transport, was clearly demonstrated later, in several studies (Martineau, 1984; Martineau et al., 1984; Bouchard and Martineau, 1985; Cadieux, 1986; De Corta, 1988; Prichonnet and Beaudry, 1990; Levasseur and Prichonnet, 1995).

Two major turning points in our understanding of the glacial paleogeography of the region east of Hudson Bay were reached in recent years. The first is the identification of the widespread ice flow toward the east-southeast in the Lake Mistassini and Chibougamau area described above, that predates the southwestward ice flow formed during deglaciation. Bouchard and Martineau (1985) proposed that the southeastward striations were formed by a glacier located to the northwest of Lake Mistassini, but to the east of Hudson Bay, since no erratics from the Hudson Bay Paleozoic Platform were found in the Lake Mistassini area. The second is the identification of a former, widespread, ice flow toward Hudson Bay in the Matagami-Chibougamau area (Veillette and Pomares, 1991), showing lateral continuity with the northwestward striations reported by Low (1889) along the coast of Hudson Bay and James Bay (Veillette, 1995; Paradis and Boisvert, 1995). Striated outcrops shaped by these two opposing flows, occur on each side of a northeast-southwest demarcation band, less than $20 \mathrm{~km}$ wide, extending from the Caniapiscau area in Québec, to northern Ontario, and passing a few km north of Chibougamau (Veillette et al., 1999). North of the line, cross-striations record a counterclockwise shift in ice flow from an early northwestward to a late southwestward flow across James Bay basin. South of the line, cross-striations record a clockwise shift in ice flow from an early southeastward flow to a late southwestward flow. While ice flow and glacial transport data toward the northwest exist north of the line, including the Hudson Bay area (Henderson, 1989; Thorleifson et al., 1993; Parent et al., 1995; Roy, 1998), data south of the line are limited to the Lake MistassiniChibougamau area, and are found mostly north of (or close to) the Grenville Front (De Corta, 1988; Cadieux, 1986; Prichonnet et al., 1984; Beaudry, 1994). The only exception is the work of Dionne (1973) who suspected the presence of Mistassini erratics in till in the Lake Saint-Jean area and later (Dionne, 1986, 1994) traced Mistassini erratics, up to $400 \mathrm{~km}$ to the southeast of Lake Mistassini, in the Tadoussac area.

\section{FIELD METHODS}

Indicator tracing studies, in support of mineral exploration, are normally carried out to identify dispersal trains leading to mineralized sources of potential economic interest. In this study, the precise location and lithological characteristics of the source rocks were known but the distribution of erratics derived from them was not. Striations from earlier ice flows are often well preserved in the lee of resistant bedrock forms striated and moulded by later ice flows. Mapping rare erratics, transported hundreds of $\mathrm{km}$ from their original locations, in the forested terrain investigated during this study, requires methods of investigation adapted to these field conditions. Previous work along the east coast of James Bay and the shorelines of reservoirs of the James Bay hydro-electric project, visited during periods of low water level, proved successful to detect rare, far-traveled erratics in wave-washed till (Veillette et al., 1999). In recent years, water levels of Hydro-Québec reservoirs were exceptionally low (Fig. 3), thus exposing large areas of wavewashed till (Fig. 4), and bare bedrock that had been protected from postglacial weathering by a sediment cover until flooding of the reservoir took place. Far away $(\sim 500 \mathrm{~km})$, down-ice from the source rocks, Mistassini erratics were found to represent

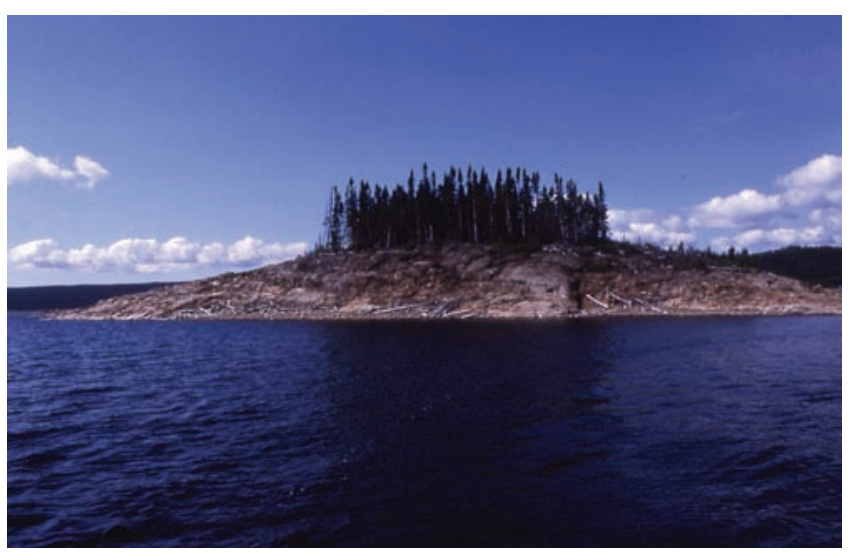

FIGURE 3. Isolated island in Manicouagan reservoir showing a 8-10 m water level drop, from the base of the tree cover to the water line.

Île isolée du réservoir Manicouagan montrant une baisse du niveau de l'eau d'environ 8-10 m, de la base du couvert forestier au niveau de l'eau. 


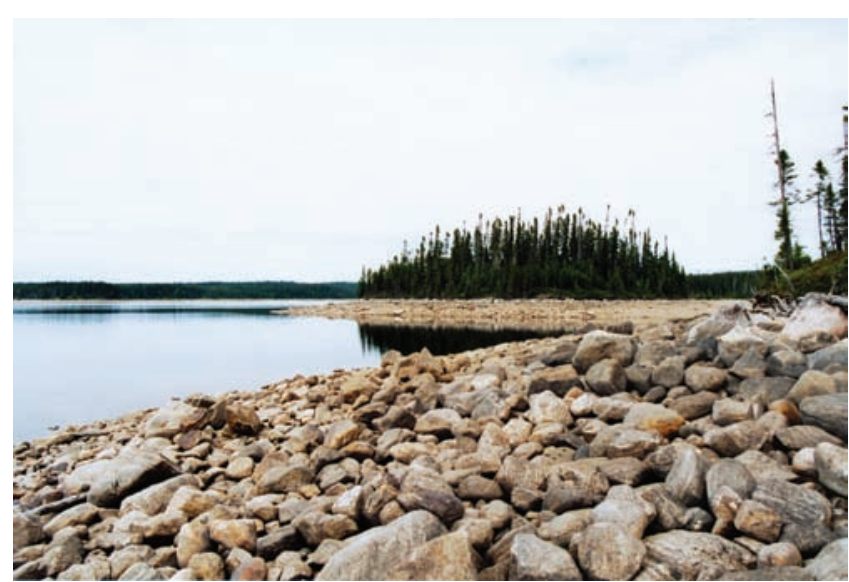

FIGURE 4. Wave-washed shoreline in thick (>2 $\mathrm{m}$ ) till. A carapace of blocks and boulders has formed reducing further erosion of the shoreline; the large seasonal water level fluctuations of the reservoirs prevent the growth of lichens on the clasts, which facilitates identification and counting.

Plage de till épais (>2 $m$ ) lessivée par l'action des vagues. Une armure de blocs s'est formée stabilisant ainsi la berge. Les fluctuations saisonnières du niveau de l'eau réduisent la croissance du lichen sur les blocs, ce qui facilite l'identification des erratiques sur le terrain.

less than $(0.006 \%)$ of the local clasts ( 1 in 17000 in the Cabonga Reservoir area) thus necessitating large samples to maximize the chances of finding some. The large area covered by this survey required a highly mobile field operation. Road cuts or borrow pits found in till and glaciofluvial deposits along roads (mostly logging roads), were visited by truck and a shallow-draft, power boat was used as a mobile field camp. A rubber raft, provided access to the shoreline.

Analytical methods used in this project are compared with those of two well-known long-distance transport studies (Salonen, 1986; Strobel and Faure, 1987), representative of most methods used in similar projects. Distances in transport studies are commonly measured along flow lines constructed from ice-flow directions derived from the orientation of icemarginal and streamlined landforms (Strobel and Faure, 1987). Flow lines are usually representative of the last regional ice flow (or flows) in a region. This approach, however, is based on the assumption that most of the transport is the result of the last ice flow expressed in landforms. Salonen (1986) took into consideration the complexity of ice-flow conditions in Finland (Hirvas and Nenonen, 1987) in his analysis of boulder transport over the whole country, and deliberately avoided areas where indicator clasts could not be clearly associated with a dominant ice flow. In this study, flow lines were drawn from manuscript maps prepared by Prest et al. (1968) for the Glacial Map of Canada. The maps were used to estimate distances of transport only where it could be determined that clast distribution was not seriously influenced by earlier ice flows. The direction of ice movement from earlier flows (not expressed in landforms) was derived from relict striations and from the position of erratics relative to that of the source rocks.

Collecting large samples from shallow pits or sections distributed along ice flow lines, and brought back to the laboratory for petrographic analysis (Strobel and Faure, 1987), or clast counting performed in the field (Salonen, 1986), are the two most common methods to estimate glacial transport. This last method was preferred because, (1) large clasts facilitate petrographic identification in the field, (2) logistical considerations (transport by small boat) prevented systematic collection of large samples for further analysis, (3) large areas of clean, wave-washed, boulder pavements, allowed the detection of distinctive erratics and the counting of thousands of clasts in short periods of time. Stretches of beach, preferably $10 \mathrm{~m}$ or more in width, and exposing hundreds of metres $(\mathrm{km}$ in places) of blocks, boulders, cobbles and coarse gravel, derived mostly from till but also from glaciofluvial deposits were selected whenever possible (Fig. 4). To provide reliable estimates of the number of clasts counted on a foot traverse along a beach, sample plots $3 \mathrm{~m}$ by $3 \mathrm{~m}$ or $5 \mathrm{~m} \times 5 \mathrm{~m}$, depending on the average diameter of the clasts, were selected and a count performed on all clasts, $5 \mathrm{~cm}$ or more in diameter, within the plots, without consideration for lithology. The search for erratics of interest was then carried out by walking balk and forth along the beach, noting, when present, the number and types of Mistassini erratics observed. The surface area covered in the foot traverse was then estimated by pacing and the number of clasts within it was estimated by proportion using the total number of clasts counted in the sample plots. Mistassini erratics and types, when present, were expressed as a percentage of the total number of clasts estimated on the foot traverse. Counts up to several tens of thousands clasts were performed in the distal parts of the study area where Mistassini erratics are extremely rare and possibly absent. Closer to the source rocks $(<100 \mathrm{~km})$, where Mistassini erratics are reasonably well represented, counts of 1000 clasts or more were usually sufficient to detect and estimate the proportion of Mistassini erratics.

\section{LITHOLOGY AND DISTRIBUTION OF THE SOURCE ROCKS}

The Proterozoic rocks of the Lake Mistassini area are located north of, and parallel to the Grenville Front (the zone of contact between the Superior and Grenville geological provinces) over a distance of about $400 \mathrm{~km}$ (Fig. 5). Smaller source areas occur within this $400 \mathrm{~km}$ stretch, since rocks from the Chibougamau Formation, from the Albanel Formation and from the Papaskwasati and Cheno Formations constitute distinct source areas. Distinguishing between sandstone erratics derived from the Papaskwasati Formation and those from the Otish Supergroup is, however, problematic, but, as will be seen later, did not impair the reconstruction of ice-flow dynamics.

The Chibougamau Formation, the oldest of the Mistassini Group, occupies an area less than $100 \mathrm{~km}^{2}$ south of Lake Mistassini and is exposed only in the Chibougamau area (Fig. 5). It consists of scattered remnants of clastic sedimentary rocks of glacial, glaciofluvial and glaciolacustrine origin, that were probably part of a more extensive sheet, and unconformably overlie granitic, gneissic and volcanic Archean rocks of the Superior Province (Long, 1973). Boulder, cobble and pebble conglomerates, lithic feldsarenites, wackes, mixtites, graded laminites with dropstones and conglomeratic sand- 


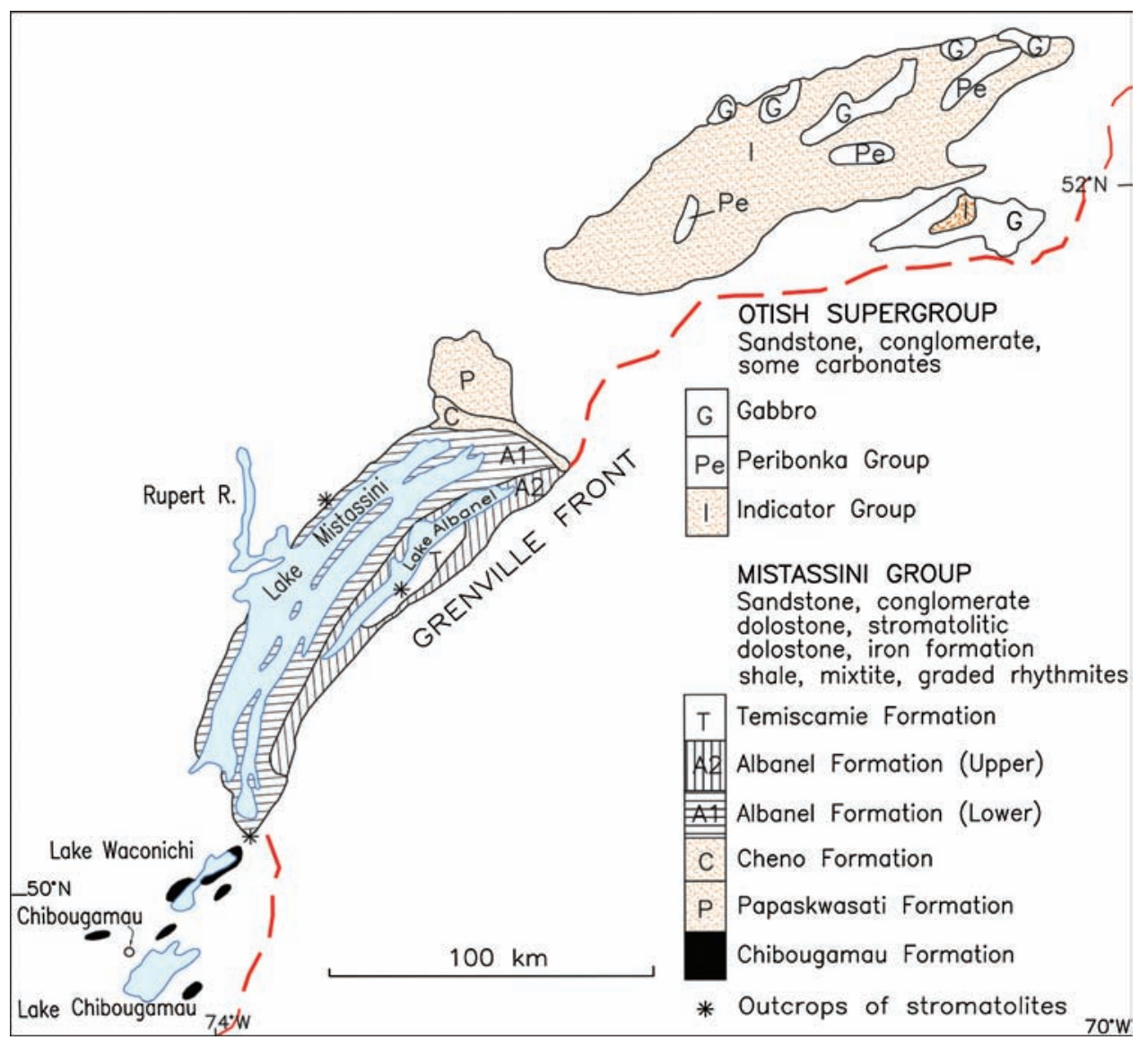

FIGURE 5. Location of rocks from the Mistassini Group and the Otish Supergroup that were used used as long-distance indicators of glacial transport during this study; the gabbro from the Otish Supergroup and iron formation from the Témiscamie Formation were not used. Adapted from Caty (1976), Hofmann (1978), Genest (1989) and Ressources naturelles du Québec (2002).

Localisation des roches du Groupe de Mistassini et du Supergroupe d'Otish utilisées comme traceurs de longue distance au cours de ce travail; le gabbro du Supergroupe d'Otish et les formations de fer de la Formation de Témiscamie n'ont pas été utilisés. Adapté de Caty (1976), Hofmann (1978), Genest (1989) et Ressources naturelles du Québec (2002). stone are the main lithologies. The absence of dolostones in rocks of the Chibougamau Formation suggests an older age than that of rocks of the Mistassini Group from which they are separated by about a kilometre of Archean gneiss (Long, 1973; Caty, 1976). Erratics from the Chibougamau Formation are of special interest to this study because of their limited occurrence and the great distances of transport recorded for some clasts.

The Mistassini Group occupies the large (7300 km²) Mistassini basin and forms a $1.5-2.0 \mathrm{~km}$ thick, assemblage of marine Aphebian deposits, mostly dolostones, gently dipping toward the southeast and capped by iron formation and black shales of the Temiscamie Formation (Fig. 5). Sequences of predominantly clastic rocks in the Papaskwasati sub-basin, located in the northeastern part of the Mistassini basin, belong to the Mistassini Group. The northwestern limit of the basin is defined by the Archean-Proterozoic unconformity that closely follows the contour of the western shore of Lake Mistassini, and the southern limit is the Grenville Front. To the southwest the carbonate rocks of the basin nearly join with the Chibougamau Formation, and to the northeast grade into the clastic rocks of the Cheno and Papaskwasati Formations (Caty, 1976). The Papaskwasati Formation (Bergeron, 1957; Caty, 1976) covers an area of about $630 \mathrm{~km}^{2}$ and consists of greenish-gray quartz sandstones and conglomerates, some of which contain thin beds of argillite (Fig. 5). The Cheno
Formation overlies the Papaskwati Formation toward the north (Fig. 5) and is overlain by the lower member of the Albanel Formation toward the south. It covers an area of about $100 \mathrm{~km}^{2}$ and consists of sandstone, conglomerate and sandy and stromatolitic dolostones (Caty, 1976).

The lower member of the Albanel Formation includes a wide variety of dolostones. Chown and Caty (1973) have estimated the thickness of the member at $610-762 \mathrm{~m}$. It covers an area of about $3800 \mathrm{~km}^{2}$ and forms the shoreline of Lake Mistassini (Fig. 5). Caty (1976) subdivided it into 6 units, from bottom to top (A) gray and stromatolitic dolostone (60 m), (B) graphitic shales interstratified with graphitic dolostone (152 m), (C) argillaceous, grey, finely bedded, dolostone (310 m), (D) black, argillaceous and siliceous dolostone, intraformational breccias and black chert at the top of the unit (152 m), (E) finely bedded brown dolostone with thin argillite beds (124 m), (F) grey dolostone, mostly massive, pink to whitish near the top of the unit (122 m). The upper member of the Albanel Formation consists predominantly of massive, pale grey to white, pink and beige dolostone in the upper part. It is located in the Lake Albanel basin and its thickness is estimated at 120 m (Fig. 5). Caty (1976) did not provide an area estimate for it but the map of Figure 5 suggests an extent exceeding $1500 \mathrm{~km}^{2}$. Erratics from the Témiscamie Formation, composed of shales and iron formations, and located between Lake Albanel and the Grenville Front, were not used in this study (Fig. 5). 
The Otish Supergroup (Genest, 1989) refers to a sequence of predominantly clastic sedimentary rocks located in the Otish basin, similar in size to the Mistassini basin, that includes the Otish Mountains (Fig. 5). The total thickness of the rocks is estimated at $2400 \mathrm{~m}$. The Indicator Group covers the whole area of the Otish Mountains $(160 \mathrm{~km} \times 50 \mathrm{~km})$ and, like the Papaskwasati Formation, rests directly on the Archean paleoregolith (Caty, 1976; Genest, 1989). The Indicator Formation of earlier studies was subdivided into a lower Matoush Formation and an upper Shikapio Formation by Genest (1989) who identified two major cycles of sedimentation over the whole area, a basal quartz conglomerate unit (member A) overlain by a sandstone unit (member B), present in both formations. The upper member $(B)$ of the Shikapio Formation corresponds to the uppermost sandstone unit identified by Chown and Caty (1973) for the Indicator Formation. It is widespread in the Otish basin and is thus of particular interest for tracing studies. It consists of, finely laminated well sorted, well rounded medium to coarse grained sandstones within large oblique stratifications. Pink, white, beige with pastel tones due to the alternance of laminations, are the typical colors. Red argillite is present locally. The formation was everywhere truncated by erosion and it is only in the vicinity of Lake Indicator that it is conformably overlain by the Peribonka Formation (Fig. 5). Most sandstone erratics of the Otish Supergroup found in the study area are thus probably derived from the Shikapio Formation. The Peribonka Group is equivalent to the Peribonka Formation of Chown and Caty (1973) to which Genest (1989) added three formations. The Group rests conformably on the quartz sandstone and the red argillite of the Shikapio Formation and in part on the Archean basement. The basal parts of the Peribonka Group are predominantly composed of conglomerates and sandstone but dolomite is also present in minor amount. The uppermost parts consist of sandstones and red conglomerates that occur mainly in the eastern parts of the basin, with the argillaceous sandstone mainly in the western part of the basin. The Peribonka Group is of limited extent compared with the Indicator Group but shows a more complex lithology.

The Papaskwasati Formation and the Indicator Group show marked stratigraphic and lithological similarities (Caty, 1976; Genest, 1989). This condition prevents a consistent distinction of erratics derived from the two source areas (Genest, personal communication, November 2005). However, as will be seen later, the rarity of carbonate rocks in the Otish Supergroup and the common association of Albanel Formation and Papaskwasati erratics were useful criteria to infer provenance in certain parts of the Grenville Province.

\section{RESULTS}

To simplify and speed up field operations the search was narrowed to three broad classes of erratics, (1) the mixite (tillite), wackes, and graded laminites (varvite) of the Chibougamau Formation, (2) the dolostones of the Albanel Formation, and (3) the sandstone and conglomerate of the Papaskwasati and Cheno formations and of the Indicator Group of the Otish Supergroup. The Chibougamau-Lake Mistassini area was visited three times between 1987 and 1999, to collect rock samples, examine outcrops of the Mistassini Group, and perform boulder counts. The last visit, in 1999, included a 2-week, 500-km boat traverse carried out along the shoreline and islands of Lake Mistassini, with short traverses a few kilometres inland in bays along the northern shore, and in the upper course of Rupert River. Results from field work in this area are first described and are followed by short descriptions of results and observations obtained at 11 other areas visited during this project.

\section{THE LAKE MISTASSINI-CHIBOUGAMAU AREA}

Lake Mistassini is the largest natural lake in Québec covering $2336 \mathrm{~km}^{2}$ with a maximum length of $161 \mathrm{~km}$ and a maximum width of $19 \mathrm{~km}$ (Fig. 2). The objectives of the August 1999 field visit were (1) to examine and collect Mistassini rocks in situ for comparaison with erratics derived from them, (2) to map striations and the distribution of erratics around the lake and in the general area surrounding it, (3) to perform clast counts of the Papaskwasati and Cheno erratics along the longitudinal axis of the lake, which is roughly parallel to the last regional flow in the area, and (4) to look for cross-cutting relationships on bedrock involving the two opposing former ice flows (northwestward and southeastward) (see Discussion). Water level was high at the time of the visit and boulder beaches were generally not as extensive as those exposed along reservoir shorelines. The distribution of erratics and striations was mapped along new logging and mining roads to the west and to the north of the lake.

Field evidence for the former southeastward flow and the clockwise shift of ice flows (Fig. 6) were first identified in the Chigougamau-Lake Mistassini area (Bouchard and Martineau, 1985). Cadieux (1986) did not find depositional or glacial transport evidence for the former southeastward ice flow identified only from striations, but recognized a younger divergent southwestward ice flow centreed about an azimuth of $210^{\circ}$, with striations showing directions up to $230^{\circ}$ and down to $180^{\circ}$. Topographic control and changes in ice-front configuration during late retreat phases were proposed by Cadieux to explain the divergence. Striations measured in the northern part of Lake Mistassini, and along roads, up to Lake Troilus (Fig. 6), and glacial transport of Mistassini erratics (below) indicate a fanning out pattern toward the west, south of Lake Mistassini. The distribution of Mistassini erratics along roads, south of Lake Mistassini, is shown on Figure 7. Earlier studies provided extensive data in support of glacial transport of Mistassini erratics toward the southwest, but few in support of the former southeastward flow. Bisson (1987), De Corta (1988) and Beaudry (1994), provided some local evidence of southeastward transport, using granite and granitoid clasts. The southwestward divergent ice-flow pattern described by Cadieux (1986), does not explain the presence of some Albanel dolostones found along the Nemiscau-Lake Troilus road (Fig. 7). Assuming that the Albanel erratics found at the northernmost location along the road come from a location, at or near, the contact with the Cheno Formation, transport along an azimuth of about $240^{\circ}$ is required. If they originate in the southern part of the Lower Albanel Formation, an ice flow toward $300^{\circ}$ is required. These limiting cases suggest that only ice flowing toward the northwest could have carried the erratics to their 


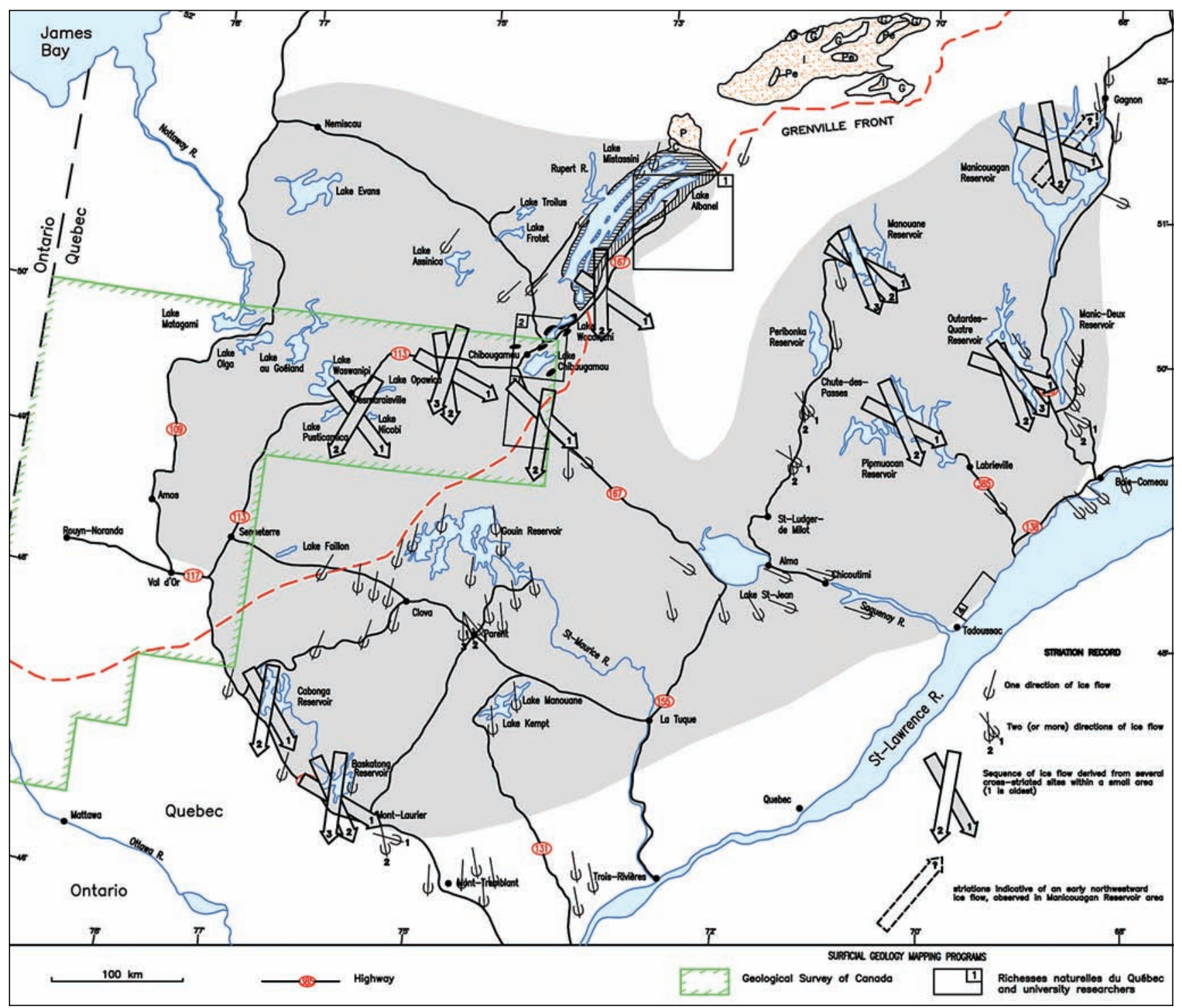

FIGURE 6. Sequence of ice flows derived from earlier work and from the mapping of cross-striated outcrops visited during this study. See Figure 2 for references of surficial geology maps and Figure 5 for the bedrock geology legend.

present position. The shoreline of Lake Mistassini and borrow pits and road cuts in the vicinity of the lake and around Chibougamau, show numerous examples of the great variety of erratics derived from rocks of the Mistassini Group. The photos of Figure 8 show some of the most common erratics found in this area and elsewhere within the study area.

\section{THE LAKE WASWANIPI-DESMARAISVILLE AREA}

Ice-flow and glacial transport data for Mistassini erratics were gathered in the early 1990s (Veillette et al., 1991), while mapping the surficial geology of the area (Fig. 2). The northern limit of the former southeastward ice flow delineated with striations lies in the Lake Waswanipi area where numerous
Séquence d'écoulements glaciaires établie à partir de travaux antérieurs et des surfaces striées montrant des recoupements répertoriées lors du présent travail. Voir la figure 2 pour les références des cartes de formation en surface et la figure 5 pour la légende de la géologie du roc.

cross-striated sites indicate an initial ice movement toward the southeast (Fig. 6). Mistassini erratics were not found west of Lake Olga (Fig. 7) and an arbitrary western limit for their distribution is set along Nottaway River. All types of Mistassini erratics, albeit rare (frequently less than $0.1 \%$ ), were found in the distal part of the dispersal area, including three clasts of stromatolitic dolostones (Fig. 7), one along the shoreline of Lake Pusticamica (Fig. 9), another along the shoreline of Lake Opawica (De Corta, 1992, personal communication), and one in an esker south of Lake Waswanipi. In spite of the longer distances of transport ( $400 \mathrm{~km}$ or more) for the sandstone of the Papaskwasati Formation compared with the Albanel dolostones (200 km or more), the sandstone erratics are more abundant than the dolostone erratics at most sites. 


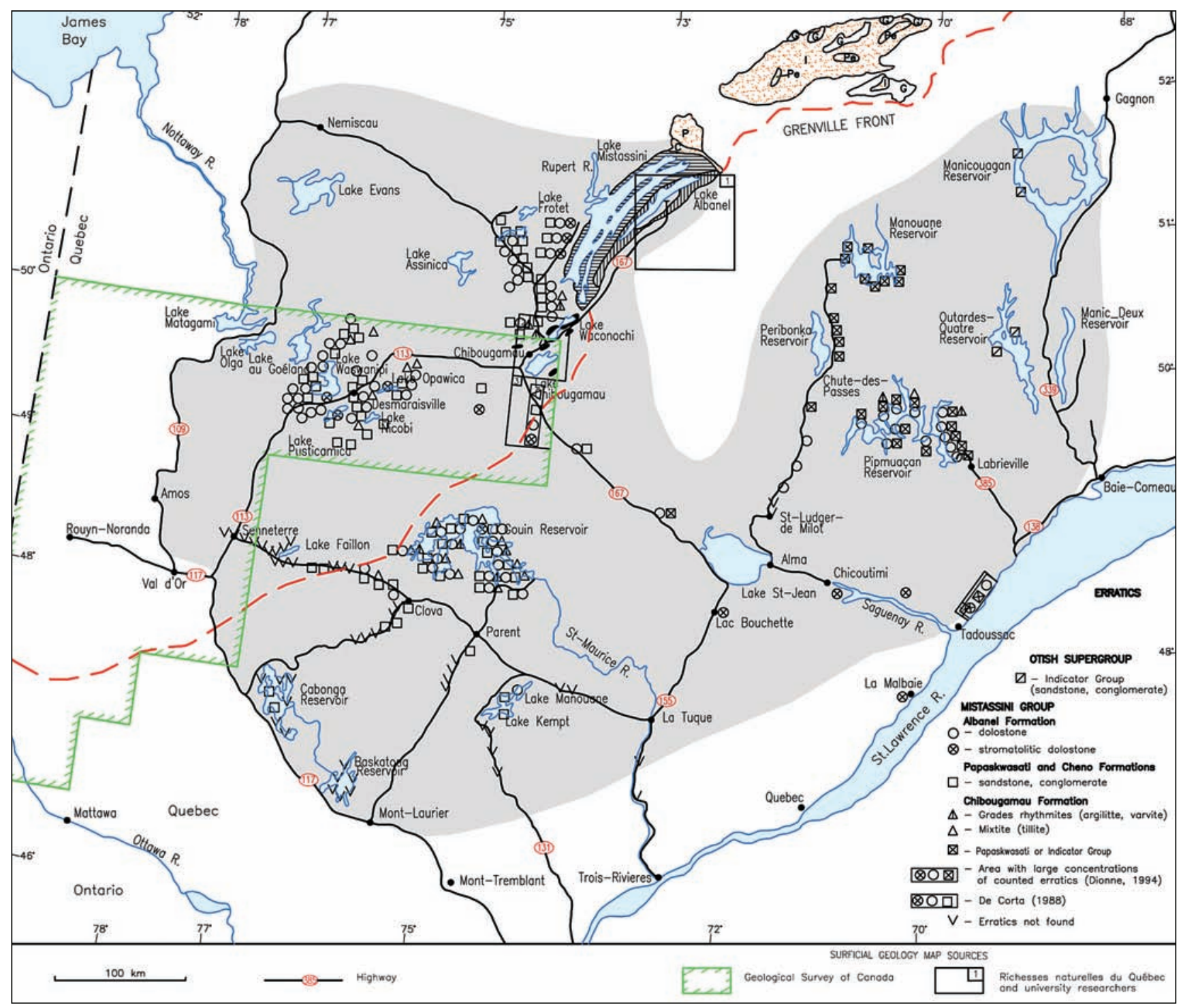

FIGURE 7. Location of sites where one or more Mistassini erratics was found away from the source rocks, and areas where extensive searches were fruitless. See Figure 2 for references of surficial geology maps and Figure 5 for the bedrock geology legend.

\section{THE SENNETERRE-LAKE FAILLON-CLOVA AREA}

Borrow pits and road cuts along the main road and surrounding logging roads between Senneterre and Clova, were investigated in October 2000 (Fig. 2). No cross-striated sites indicative of ice flows older than the last southwestward ice flow, and no Mistassini erratics could be found in 600000 clasts examined in 9 borrow pits located in glaciofluvial deposits between Senneterre and Lake Faillon (Figs. 6-7). The westernmost erratic found was a large Papaskwasati sandstone boulder (Fig. 10) observed in a till section to the southeast of Lake Faillon. The boulder lies at more than $450 \mathrm{~km}$ down-ice from the distal contact of the Papaskwasati Formation. From this site eastward to Clova, Mistassini erratics are present in
Endroits où un ou plusieurs erratiques du Mistassini ont été trouvés, loin des roches source, et des endroits où aucun erratique n'a été observé. Voir la figure 2 pour les références des cartes de formation en surface et la figure 5 pour la légende de la géologie du roc.

surficial deposits, but extremely rare; Papaskwasati sandstone clasts were found up to $30 \mathrm{~km}$ south of Clova (Fig. 7).

\section{THE PARENT-GOUIN RESERVOIR AREA}

Flooded in 1918, the Gouin Reservoir, is located about $50 \mathrm{~km}$ north of the village of Parent (Fig. 2). It covers $1302 \mathrm{~km}^{2}$ and extends $100 \mathrm{~km}$ east-west and $70 \mathrm{~km}$ north-south. It consists of elongated bays, broken up by hundreds of small islands, carved in till and glaciofluvial deposits, and bedrock outcrops. Its northern shore is $110 \mathrm{~km}$ to the southwest of the distal contact of the Chibougamau Formation, $170 \mathrm{~km}$ from the Albanel Formation and $300 \mathrm{~km}$ from the Papaskwasati Formation. It is underlain by Archean granitic gneiss and gran- 

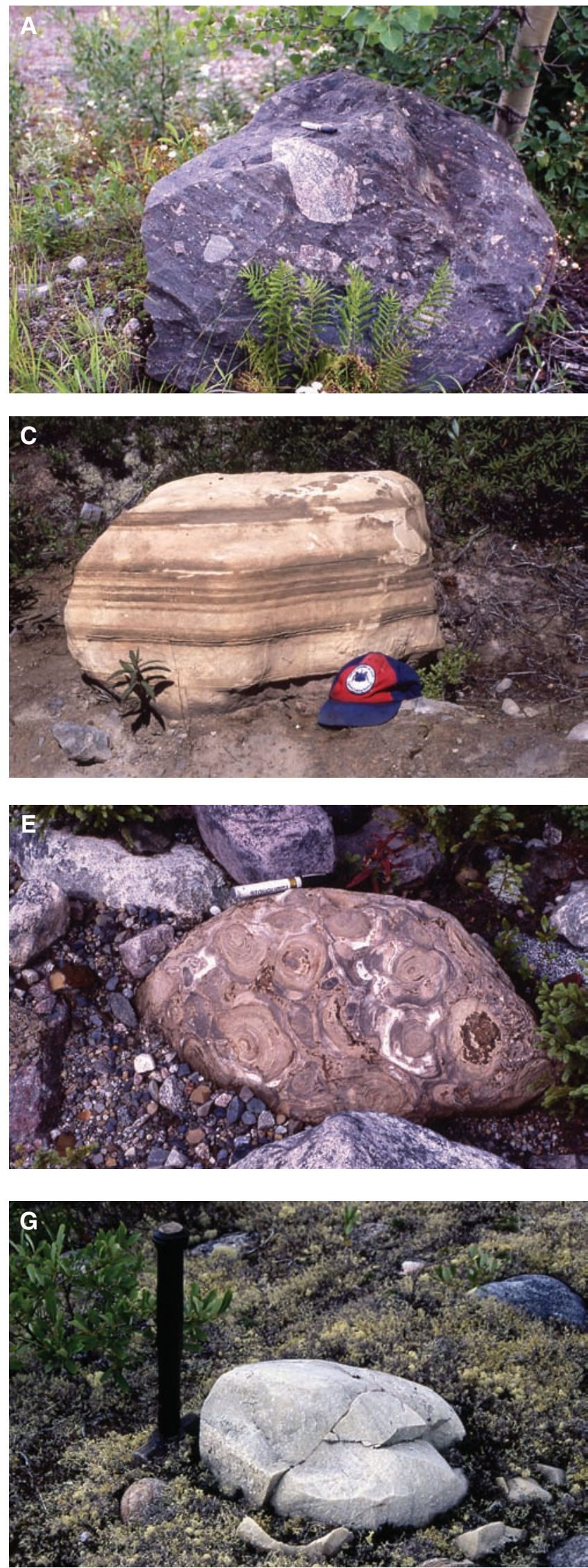
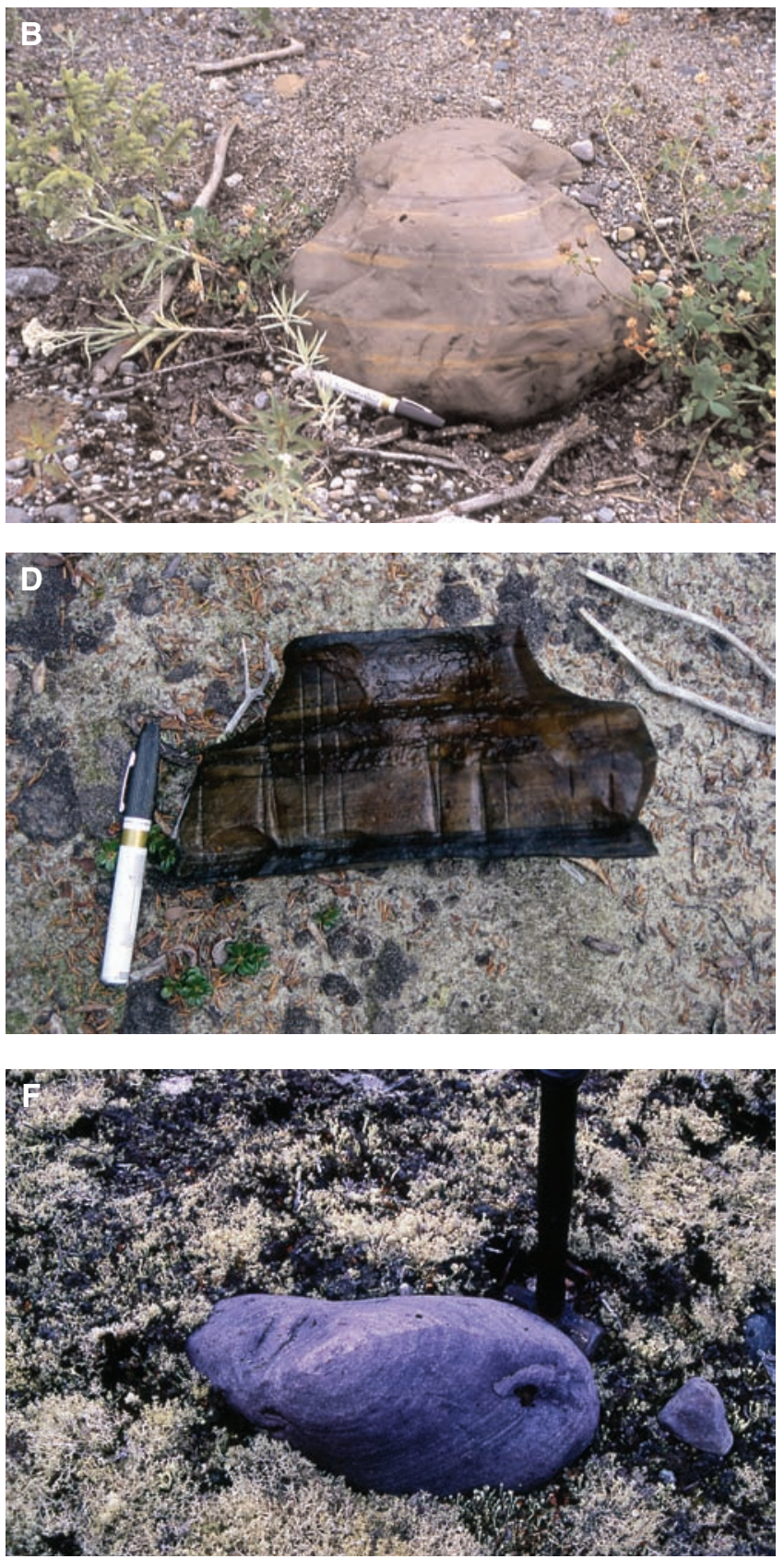

FIGURE 8. (A) Erratic of Chibougamau Formation tillite. (B) Erratic of Chibougamau Formation varvite. (C) Erratic of banded dolostone from the Albanel Formation. (D) Erratic of cherty dolostone from the Albanel Formation. (E) Erratic of stromatolitic dolostone from the Albanel Formation. (F) Erratic of banded sandstone from the Cheno Formation. (G) Erratic of banded sandstone from the Papaskwasati Formation.

(A) Erratique de tillite de la Formation de Chibougamau. (B) Erratique de varvite de la Formation de Chibougamau. (C) Erratique de dolomie litée de la Formation d'Albanel. (D) Erratique de dolomie avec couche de chert de la Formation d'Albanel. (E) Erratique de dolomie à stromatolites de la Formation d'Albanel. (F) Erratique de grès lité de la Formation de Chéno. (G) Erratique de grès lité de la Formation de Papaskwasati. 


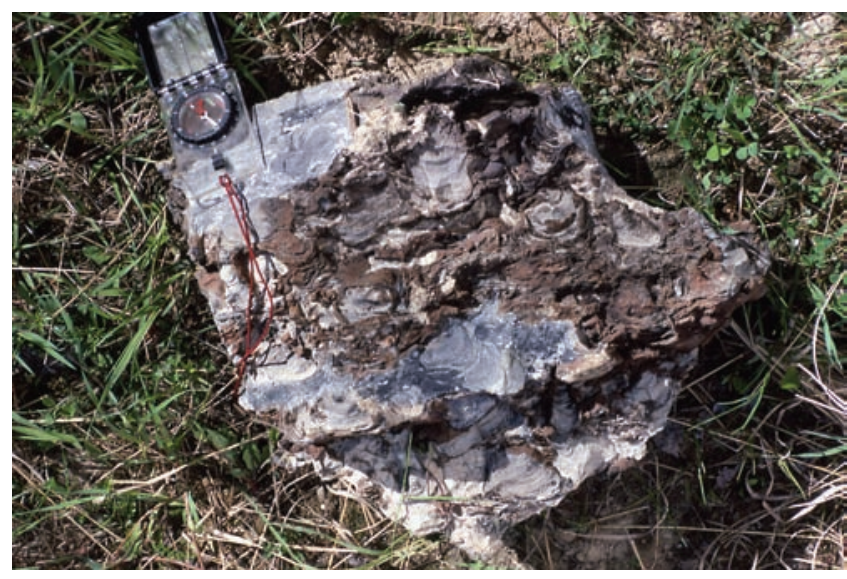

FIGURE 9. Angular block of stromatolitic dolostone found on the shoreline of Lake Pusticamica. The minimum distance of travel for the fragment is $200 \mathrm{~km}$ down-ice from the nearest known occurrence of the source rock, and could be up to $350 \mathrm{~km}$ depending on the location of the source rock within Lake Mistassini basin. See Figure 5 for known locations of outcrops of stromatolitic dolostone in the Albanel Formation.

Bloc anguleux de dolomie à stromatolites trouvé sur les rives du lac Pusticamica. Ce fragment a été transporté sur une distance minimale de $200 \mathrm{~km}$ à l'aval-glaciaire du plus proche affleurement connu et pourrait provenir d'aussi loin que $350 \mathrm{~km}$, selon la localisation des roches sources à l'Intérieur du bassin du lac Mistassini. Voir la figure 5 pour la localisation de ces affleurements dans la Formation d'Albanel.

itoids and Proterozoic granite and pegmatite (Ressources naturelles du Québec, 2002). At the time of the visit, late summer 2000, the water level was only $1 \mathrm{~m}$ below its seasonal maximum. Weathering destroyed most striated surfaces located above the high water line. Striations indicate a prevalent south to southwestward ice movement in the western half of the reservoir and toward the southeast in the eastern half (Fig. 8). Cross-striated sites are present along the shoreline but are poorly-developed and unreliable in most cases to infer former directions of ice flow. Borrow pits, roads cuts and bedrock outcrops were investigated in the vicinity of Parent. Striated facets on a bedrock outcrop north of the village suggest a gradual shift from an early eastward flow $\left(110^{\circ}\right)$ to a southward flow $\left(170^{\circ}\right)$. Cross-striated sites such as this one, however, are too rare to support a distinct clockwise shift in ice movement.

Mistassini erratics of all types occur everywhere along the shoreline of the reservoir, in till and in glaciofluvial deposits (Fig. 9). Detailed clast counts were done at 18 locations along the reservoir shoreline (Table I). Dolostones from the Albanel Formation and sandstone from the Papaskwasati (and Cheno) formations were present at most sites. Graywakes, graded laminites (varvite) and conglomerate (tillite) from the Chibougamau Formation are well represented given the small extent of these source rocks. Two stromatolitic dolostones were also found. A cobble of Papaskwasati sandstone was found about $15 \mathrm{~km}$ south of Parent.

Dolostone and sandstone erratics, the most abundant, account for only $0.098 \%$ and $0.10 \%$ of all counted clasts. Erratics of Papaskwasati sandstone outnumber erratics from the Albanel Formation, in spite of a much smaller source area for the sandstone $\left(730 \mathrm{~km}^{2}\right.$ for the Papaskwasati and Cheno

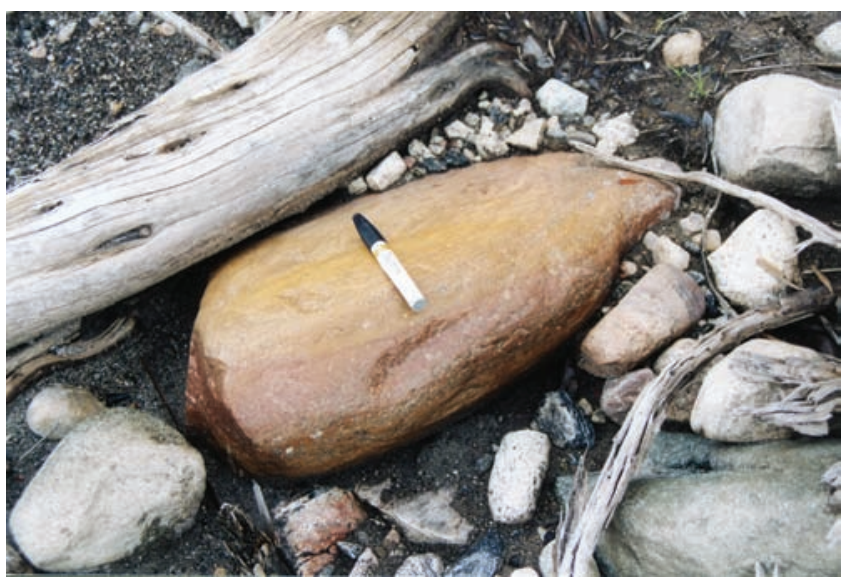

FIGURE 10. Bullet shape boulder of Papaskwasati Formation fine conglomeritic sandstone, found in a road cut in till, about $25 \mathrm{~km}$ east of Lake Faillon (Fig. 7).

Bloc de grès à conglomérat fin, en forme de fer à repasser, de la Formation de Papaskwasati, trouvé dans une coupe de till, à environ $25 \mathrm{~km}$ à l'est du lac Faillon (Fig. 7).

formations, versus $3800 \mathrm{~km}^{2}$ for the Lower member of the Albanel Formation only), and a greater distance of travel $(170 \mathrm{~km}$ from the distal contact of the lower member of the Albanel Formation to the north shore of the Gouin Reservoir, and $310 \mathrm{~km}$ from the distal contact of the Papaskwasati Formation). This difference in abundance suggests that more dolostone clasts were destroyed either during transport or since their deposition, than the more resistant quartz sandstone clasts. Sandstone clasts were found to frequently exceed boulder size, while dolostone clasts are generally smaller. Postglacial weathering also destroyed dolostone clasts, 18 of the 146 dolostone clasts counted along the shoreline were in different stages of break-down (see Discussion). With $39(11 \%)$ clasts out of 340 Mistassini erratics, the small area of occurrence (less than $100 \mathrm{~km}^{2}$ ) of the Chibougamau Formation is well represented.

\section{LAKE MANOUANE-LAKE KEMPT AREA}

Lake Manouane is located $50 \mathrm{~km}$ south of Parent and covers about $50 \mathrm{~km}^{2}$ (Fig. 2). About $45 \mathrm{~km}$ of shoreline were inspected in late summer 2001. Striations indicate a dominant south-southeastward ice movement without any indication of meaningful cross-cutting relationships indicative of earlier ice flows. Counts of about 145000 clasts produced 4 Papaskwasati sandstone clasts and one Albanel dolostone clast (Figs. 6-7). The southernmost sandstone clast lies at about $475 \mathrm{~km}$ downice from the distal contact of the Papakwasati Formation. Roadside inspections south of Lake Kempt did not produce any more Mistassini erratics. The exposures visited, however, were not extensive and consisted mostly of shallow road cuts. 
TABLE I

Striations and clast counts along Gouin Reservoir shoreline and in surrounding area

\begin{tabular}{|c|c|c|c|c|c|c|c|}
\hline \multirow[t]{2}{*}{ Stop number } & \multirow{2}{*}{$\begin{array}{c}\text { Striations } \\
\text { Azimuth }\left({ }^{\circ}\right)\end{array}$} & \multirow[t]{2}{*}{ Clast count } & \multirow{2}{*}{$\begin{array}{c}\text { Albanel } \\
\text { Dolostone }\end{array}$} & \multirow{2}{*}{$\begin{array}{l}\text { Stromatolitic } \\
\text { Dolostone }\end{array}$} & \multirow{2}{*}{$\begin{array}{l}\text { Papaskwasati } \\
\text { Cheno Fm. }\end{array}$} & \multicolumn{2}{|c|}{ Chibougamau Fm. } \\
\hline & & & & & & Tillite & Varvite \\
\hline $00-001$ & & 3000 & 0 & 0 & 0 & 0 & 0 \\
\hline $00-002$ & 168 & & & & & & \\
\hline $00-003$ & 160 & 5000 & 0 & 0 & 2 & 1 & 0 \\
\hline 00-004 & $\begin{array}{l}148(1) \\
166(2)\end{array}$ & 5000 & 1 & 0 & 0 & & 0 \\
\hline $00-005$ & 162 & 5000 & 9 & 0 & 10 & & 0 \\
\hline $00-006$ & & 2000 & 0 & 0 & 0 & 1 & 0 \\
\hline $00-007$ & 185 & 10000 & 6 & 0 & 12 & 1 & 0 \\
\hline $00-008$ & & 5000 & 2 & 0 & 6 & 4 & 0 \\
\hline $00-009$ & & 8000 & 18 & 0 & 22 & 12 & 3 \\
\hline $00-010$ & & 1000 & 2 & 0 & 0 & 0 & 1 \\
\hline $00-011$ & 175 & 2000 & 1 & 0 & 2 & 0 & 0 \\
\hline 00-012 & & 10000 & 5 & 0 & 6 & 0 & 0 \\
\hline $00-013$ & & 20000 & 4 & 0 & 12 & 3 & 0 \\
\hline $00-015$ & 180 & 5000 & 12 & 0 & 6 & 0 & 0 \\
\hline $00-016$ & & 40000 & 60 & 0 & 40 & 1 & 1 \\
\hline 00-017 & & 15000 & 6 & 0 & 10 & 2 & 1 \\
\hline $00-018$ & & 5000 & 5 & 0 & 8 & 2 & 0 \\
\hline 00-019 & 170 & & & & & & \\
\hline $00-020$ & 185 & & & & & & \\
\hline $00-021$ & 185 & & & & & & \\
\hline $00-022$ & & yes & $?$ & & & yes & \\
\hline $00-023$ & & 5000 & 12 & & 16 & 3 & \\
\hline $00-023 \mathrm{~A}$ & & & & 1 & & & 1 \\
\hline $00-024$ & & & 1 & 1 & & 0 & 0 \\
\hline $00-025$ & & 2000 & 3 & 0 & 1 & 2 & 0 \\
\hline $00-026$ & 170 & & & & & & \\
\hline $00-027$ & $\begin{array}{l}165(1) \\
140(2)\end{array}$ & & & & & & \\
\hline $00-028$ & 158 & & & & & & \\
\hline Total & & 149000 & 146 & 2 & 153 & 32 & 7 \\
\hline
\end{tabular}

\section{CABONGA RESERVOIR}

The Cabonga Reservoir, located about $100 \mathrm{~km}$ north of Mont-Laurier, covers $404 \mathrm{~km}^{2}$, with several islands and deep bays (Fig. 2). It was flooded in the mid 1920s. At the time of the visit, in September 2000, the water level was $2 \mathrm{~m}$ below its seasonal high. The area is underlain by migmatite and some marble (Ressources naturelles du Québec, 2002). About $85 \mathrm{~km}$ of shoreline was visited. Three outcrops showing striated facets from an earlier flow toward $150^{\circ}-155^{\circ}$ crossed by striations from a last regional flow toward $210^{\circ}$ were located (Fig. 6). About 250000 clasts were counted at 7 sites around the reservoir. No clast of Albanel dolostones were noted, and 9 cobbles and boulders of hard sandstone of orangey color when humid, similar to the Papaskwasati boulders seen further north, were observed at two locations with counts of 50000 clasts and 100000 clasts respectively (Fig. 7). These are tentatively considered to be derived from the Papaskwasati Formation and were retained for further analysis. If these clasts, located about $550 \mathrm{~km}$ down-ice from the distal contact of the Papaskwasati Formation, are from the Papaskwasati Formation or from the Otish Supergroup, they show the longest transport distances recorded in this study.

\section{THE MONT-LAURIER-BASKATONG RESERVOIR AREA}

The Baskatong reservoir, located about $30 \mathrm{~km}$ northwest of Mont-Laurier, covers $330 \mathrm{~km}^{2}$ (Fig. 2). With its northern shore located $400 \mathrm{~km}$ southwest of the Chibougamau Formation and $550 \mathrm{~km}$ southwest of the Papaskwasati Formation, it is 
the most distant reservoir from the source rocks. At the time of the visit, in late summer 1999, water level was $2 \mathrm{~m}$ below the seasonal maximum. It is underlain by Archean migmatite and gneiss, Proterozoic paragneiss, quartzite, marble and dolomite (Ressources naturelles du Québec, 2002). Most of the shoreline is eroded in till and several islands consist entirely of bare, wave-washed bedrock, from which striations formed in the higher parts, were destroyed by weathering. The best striated surfaces were found at or near the water line. The presence of calcareous rocks may account for the intense weathering of bedrock. The 18 striated surfaces studied indicate a consistent clockwise shift in ice flow starting with an initial ice movement toward $120^{\circ}-140^{\circ}$ ending with the regional ice flow toward $200^{\circ}-210^{\circ}$, well-expressed in streamlined landforms (Fig. 6). No Mistassini erratics were found among the estimated 250000 clasts observed along the $90 \mathrm{~km}$ of shoreline inspected. Inspection of borrow pits and road cuts along access roads to the reservoir and the main road system in the Mont-Laurier general area, failed to reveal any Mistassini erratics. Cross-striated sites around Mont-Laurier suggest a similar ice-flow chronology to that found in Baskatong reservoir (Fig. 6).

All sites described to this point were located down-ice from the last regional ice flows. Long-distance transport from the Lake Mistassini area to these sites correspond to the glacial lineation mapped from airphotos or satellite imagery (Fig. 11).

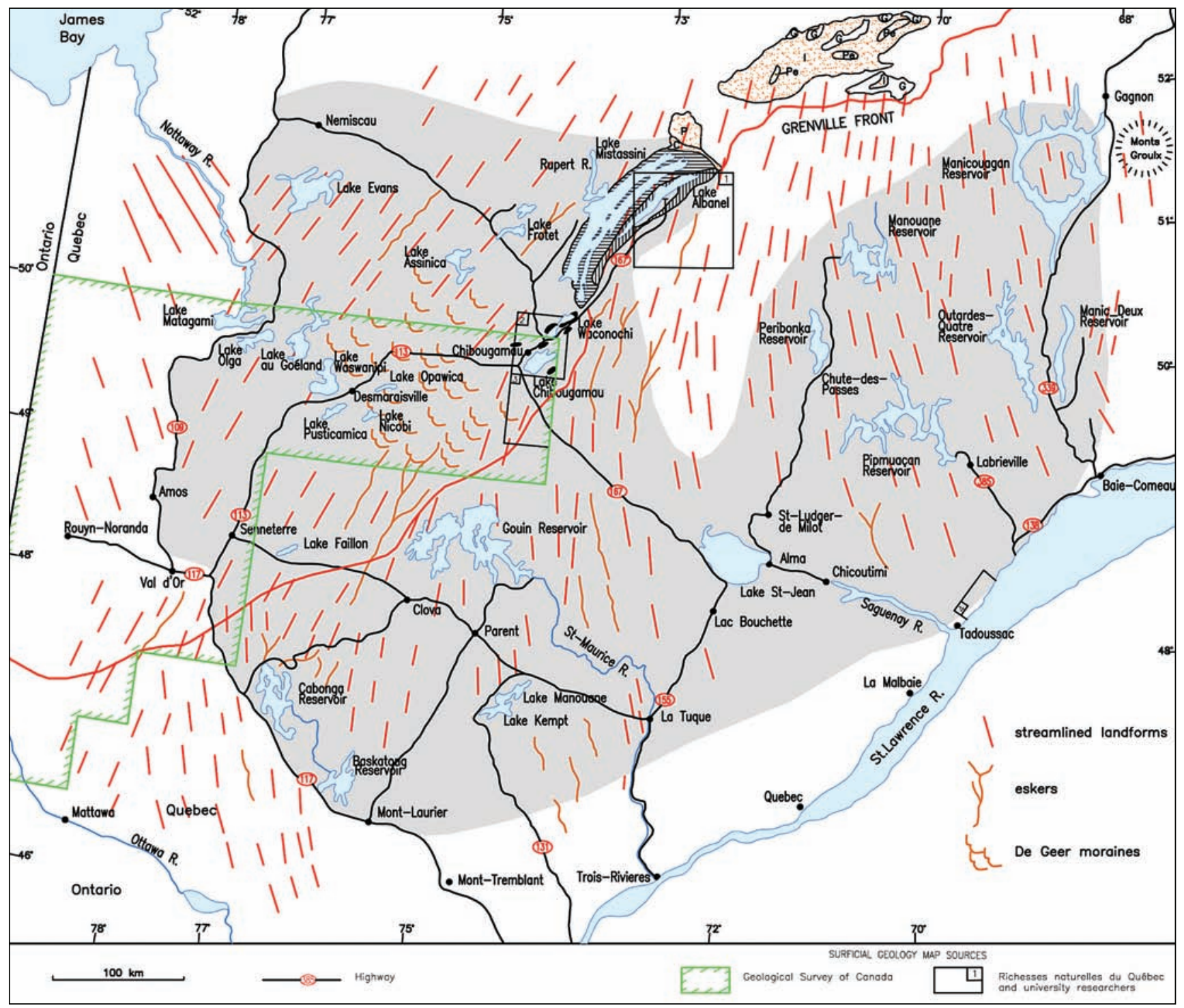

FIGURE 11. Glacial lineation map for the study area generalized from manuscript maps used by Prest et al. (1968) for the compilation of the Glacial Map of Canada (Terrain Sciences Archives, Geological Survey of Canada, Ottawa).
Carte montrant la linéation glaciaire de la région à l'étude, reconstituée à partir de cartes manuscrites ayant servies à la compilation de la Carte glaciaire du Canada par Prest et al. (1968) (Archives de la Division des terrains de la Commission géologique du Canada, Ottawa). 
Transport of Mistassini erratics to the sites and reservoirs described below, all located east of Lake Saint-Jean, cannot, however, be explained by the patterns of streamlined deglaciation landforms and from the striations associated with them.

\section{MANICOUAGAN RESERVOIR}

Located $220 \mathrm{~km}$ north of Baie-Comeau, the Manicouagan Reservoir occupies the ring shaped depression formed by the Manicouagan crater (Grieve and Head, 1983) and covers about $1000 \mathrm{~km}^{2}$ (Fig. 2). The large island inside the ring consists predominantly of Mesozoic melt rocks. Archean gneiss with sections of Proterozoic mafic rocks and anorthosite form the exterior shoreline (Murtaugh, 1976). A $650 \mathrm{~km}$ boat traverse was carried out along both the interior and exterior shorelines and into some bays, in late summer 1998. The water level of the reservoir was then about 8-10 m below its historic high and $6 \mathrm{~m}$ below the level of previous years, thus exposing extensive surfaces of bare bedrock and boulder beaches (see Fig. 3). The flooding and consequent shoreline erosion took place in the late 1960s- early 1970s. Striations measured at 31 sites around the shoreline indicate a dominant last ice flow toward $160^{\circ}-170^{\circ}$ (Fig. 6), that is clearly expressed by the orientation of the glacial lineation in the large central island displayed on a Radarsat image (Fig. 12). Two excellent cross-striated outcrops, on small islands a few $\mathrm{km}$ apart in the northern part of the reservoir, show striated surfaces formed by a former ice movement toward $105^{\circ}-110^{\circ}$, crossed by a last one toward $180^{\circ}$, expressed in north-south streamlined landforms, north of the islands along the exterior shoreline (Fig. 12). Both sites occur slightly above water level. The following interpretation for the sequence of events is suggested, (1) eastward ice movement formed large (1.0 m wide) polished and striated grooves, several metres long preserved in the lee side (relative to the last ice movement) of bedrock bosses, (2) the grooves were then infilled by till deposited by the same glacier that formed them, (3) the last southward moving glacier flowed over the site but did not remove the protective till cover masking the eastward grooves and striations, and deposited its own till, (4) wave action removed the older till masking the grooves and the last till above it, thus exposing the older and the younger striated surfaces. One other striated site found in the western part of the reservoir, shows evidence of a former eastward ice flow.

The most intriguing striated surfaces are not, however, related to any of the two ice movements discussed above. Two sites showing relict striated surfaces indicative of ice movements toward $40^{\circ}$ and $30^{\circ}$ were observed in the eastern part of the reservoir, and a third one toward $55^{\circ}$ along the main road east of the reservoir. All three are crossed by southeastward striations and occur within $20 \mathrm{~km}$ of each other. A tentative correlation for these former striations with the oldest northeastward striated surfaces observed in southern Labrador (Klassen and Thompson, 1993) and in the Caniapiscau area (Veillette et al., 1999), and attributed to ice dispersal centres located in the Québec highlands by these authors, is proposed.

Mistassin erratics were not observed along the reservoir shoreline but, at the time, no extensive searches were carried out. Murtaugh (1976), while mapping the Manicouagan impact structure, prior to the flooding of the reservoir, reported erratics of pink quartzite of unknown provenance. These are thought to be similar to the sandstone/quartzite erratics observed on the shoreline of Outardes-4 Reservoir (Fig. 7), believed to originate from the Otish Supergroup. Striations formed by the former eastward ice movement described in the northern part of the reservoir indicates provenance from the Otish Supergroup. Inspection of borrow pits, road cuts and outcrops along Highway 389, up to the former townsite of Gagnon and around the Lake Jeannine open pit mine, did not reveal any Mistassini erratics. Striations as shown on Figure 6 indicate a prominent southward to southeastward flow, with local deflections toward the southwest around the Monts Groulx, located east of the reservoir (see Fig. 11).

\section{THE OUTARDES-QUATRE RESERVOIR AND SURROUNDING AREA}

The reservoir is about $100 \mathrm{~km}$ long and up to $10 \mathrm{~km}$ wide and is confined to the valley of the Outardes River (Fig. 2). The dam holding it was built in the late 1960s as part of the Outardes-Manicouagan hydro-electric project. Proterozoic migmatite is exposed along most of the shoreline. At the time of the visit in late summer 1998, reservoir level was about $2 \mathrm{~m}$ below the high water line. Striations were measured at 11 sites along the shoreline. The most common pattern shows a first ice movement toward $160^{\circ}-170^{\circ}$ crossed by a younger one toward $140^{\circ}-150^{\circ}$, suggesting a late shift toward the east due to drawdown (Occhietti et al., 2001) as one approaches the St. Lawrence River Valley (Fig. 8). Faint striations indicative of a former eastward $\left(105^{\circ}\right)$ ice movement crossed by a younger one toward the southeast, were observed at one location only along the shoreline. The scarcity of older striated surfaces is due to weathering of the bedrock surface; in several locations, striations were preserved only on quartz and other resistant veins sticking out from the host rock surface due to differential weathering. Measurements at 14 sites showing a similar iceflow sequence as the one observed on the reservoir, were obtained from bedrock outcrops along logging roads in the general area. One outcrop showed a clear relative chronology $\left(110^{\circ}\right.$ crossed by $\left.160^{\circ}\right)$. East of Manic-Deux Reservoir, the dominant ice flow was toward $150^{\circ}-160^{\circ}$. The clockwise shift in ice flows probably affected the Outardes-Quatre area, but the counter-clockwise shift due to drawdown, makes it difficult to demonstrate it conclusively on the sole basis of striations. Blocks and boulders of pink and beige sandstone believed to be derived from the Indicator Group of the Otish Supergroup were observed in the northern part of the reservoir (Fig. 7). Erratics from the Albanel and the Chibougamau Formations were not found along the shoreline nor in borrow pits or road cuts along logging roads.

\section{THE BAIE-COMEAU AREA}

No Mistassini erratics were found in the Baie-Comeau area during limited searches around the town (Fig. 2). Dionne noted that Ragueneau, located about $30 \mathrm{~km}$ west of Baie-Comeau, is the easternmost locality where Mistassini dolostone erratics were observed along the north shore of the St. Lawrence River 
estuary (Dionne, personal communication, 2006). Bedrock outcrops were briefly examined over a distance of about $30 \mathrm{~km}$ to the east and to the west of Baie-Comeau, along Highway 138, and 9 striated sites were measured. The inflection toward the Gulf of St. Lawrence, observed in the southern part of Outardes-Quatre reservoir, is more pronounced here and most striated sites indicate ice flow directions toward $130^{\circ}-140^{\circ}$, making it difficult to detect striations left by an earlier ice flow of similar orientation, if present, ever (Fig. 6).

\section{THE PIPMUACAN RESERVOIR-LABRIEVILLE AREA}

The Pipmuacan Reservoir, built in the early 1900s, is a widening of Betsiamites River, that covers about $780 \mathrm{~km}^{2}$ and

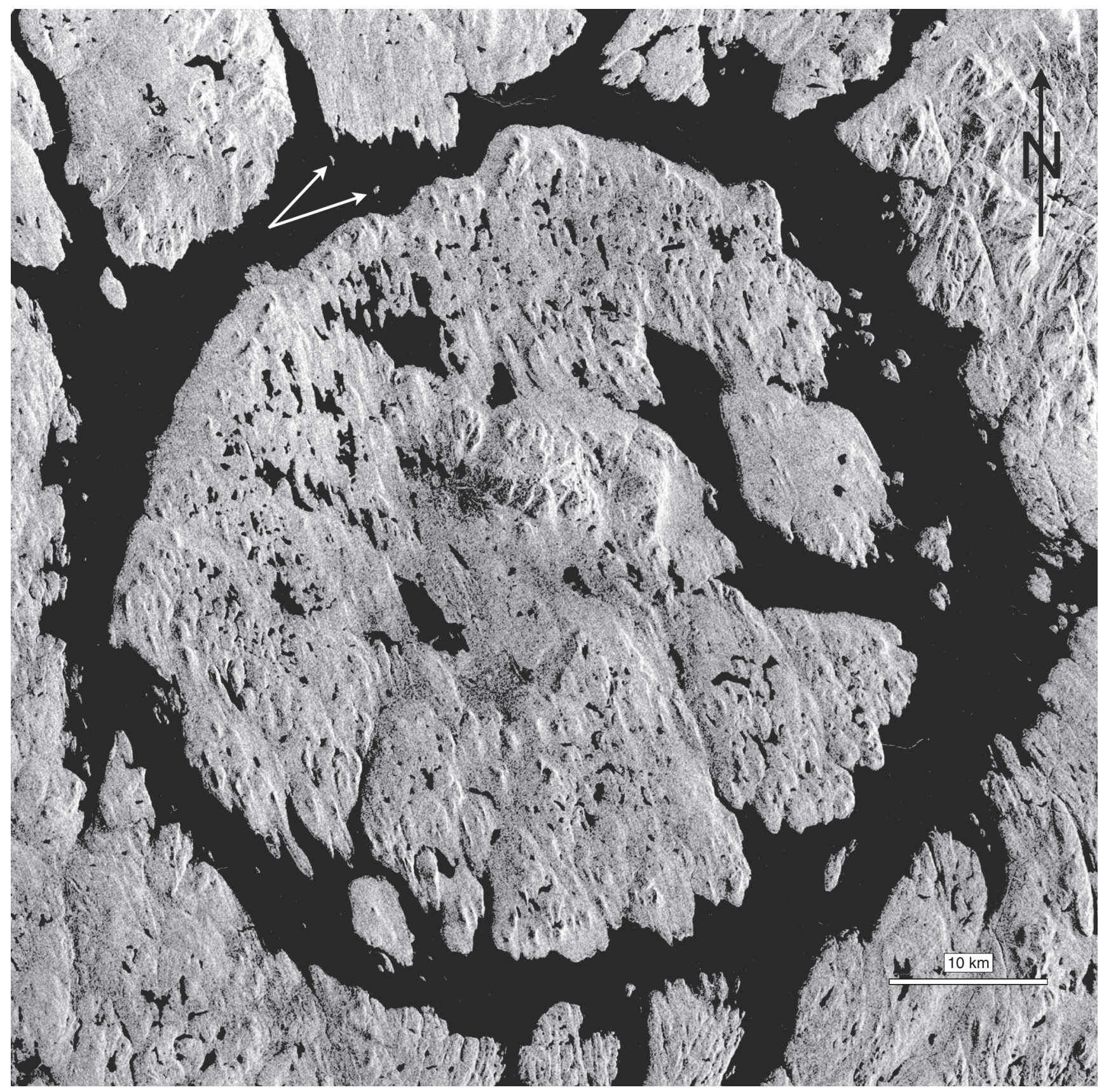

FIGURE 12. Satellite image of Manicouagan Reservoir; note the distinct NW-SE glacial lineation and crag and tail features across the René-Levasseur island (the large circular island within the ring) indicating southeastward moving ice; cross-striated outcrops on the two small islands in the northern part of the reservoir (arrows) indicate that a former ice flow toward $105^{\circ}-110^{\circ}$ was overprinted by a last one toward $180^{\circ}$ (Radarsat-1 image taken August $10^{\text {th }}, 1996$ ).
Image satellitaire du réservoir Manicougan; les formes profilées témoignent d'une direction d'écoulement des glaces vers le sud-est sur l'île René-Levasseur, la grande île circulaire au centre de l'anneau; des stries entre-croisées, sur deux petites îles du nord du réservoir (voir flèches) indiquent qu'un premier mouvement des glaces vers $105^{\circ}-110^{\circ}$ fut recoupé par un dernier vers $180^{\circ}$ (image Radarsat- $1 \mathrm{du}$ 10 août, 1996). 
extends about $150 \mathrm{~km}$ east-west and $19 \mathrm{~km}$ north-south in its widest part (Fig. 2). Its surface is broken up by numerous islands giving access to a wide variety of shoreline deposits. Its configuration is similar to that of the Gouin Reservoir, in that its widest extent is more or less perpendicular to ice-flow directions, making it a valuable site for the mapping of fartraveled erratics. Its northwestern shore is located $260 \mathrm{~km}$ to the southeast of the Chibougamau Formation and other rocks of the Mistassini Group including the Papaskwasati Formation, and its southeastern shore is at $325 \mathrm{~km}$. Bedrock exposed along the shoreline consists predominantly of deeply weathered Proterozoic anorthosite and Archean gneiss. At the time of the visit in late summer 1998, water level was about $3 \mathrm{~m}$ below the seasonal high level. Striations were recorded at 14 sites (Table II), 5 of which show clear striated facets made by an earlier ice flow toward the east-southeast crossed by younger striations toward the south-southeast (Fig. 6). In several places below the high water line, large grooves, up to $0.50 \mathrm{~m}$ wide and a few metres long, or roches moutonnées from which striations were obliterated by weathering, constitute strong erosional evidence that the area was once covered by a glacier flowing toward the east-southeast. In spite of strong differential weathering, striations were preserved locally on more resistant lithologies.
A wide variety of Mistassini dolostone and sandstone erratics occur everywhere along the shoreline. The Proterozoic sandstone clasts outnumber the dolostone clasts 8 to 1 and the overall number of Mistassini erratics is nearly $1 \%$ (Fig. 7 ). Erratics from the Mistassini Group-Otish Supergroup, were found at everyone of the 14 sites investigated. Graded laminites (varvite) from the Chibougamau Formation were found at two locations and flakes from black wackes believed to be derived from the Chibougamau Formation are also present (not counted). Erratics of the Papaskwasati and/or the Otish Supergroup, greatly outnumber dolostone erratics from the Albanel Formation. The distance of travel for dolostone erratics from the Albanel Formation and sandstone erratics from the Papaskwasati Formation, from their southern contact with Shield rocks to the central north shore of Pipmuacan Reservoir is roughly similar (about $260 \mathrm{~km}$ ), if it is assumed that both types of erratics were carried by a general eastward to southeastward ice flow. The greater abundance of the sandstone clasts suggests that a significant part of the dolostones were destroyed during glacial transport or since deposition. About $20 \%$ of the dolostone clasts observed along the shorelines showed signs of destruction by chemical postglacial weathering. The presence of Chibougamau Formation erratics in Pipmuacan Reservoir requires a former ice movement

TABLE II

Striations and clast counts along Pipmuacan Reservoir shoreline and surrounding area

\begin{tabular}{|c|c|c|c|c|c|c|c|}
\hline \multirow[t]{2}{*}{ Stop number } & \multirow{2}{*}{$\begin{array}{l}\text { Striations } \\
\text { Azimuth }\left({ }^{\circ}\right)\end{array}$} & \multirow[t]{2}{*}{ Clast count } & \multirow{2}{*}{$\begin{array}{l}\text { Albanel } \\
\text { Dolostone }\end{array}$} & \multirow{2}{*}{$\begin{array}{l}\text { Stromatolitic } \\
\text { Dolostone }\end{array}$} & \multirow{2}{*}{$\begin{array}{l}\text { Papaskwasati } \\
\text { Cheno Fm. }\end{array}$} & \multicolumn{2}{|c|}{ Chibougamau Fm. } \\
\hline & & & & & & Tillite & Varvite \\
\hline $98-079$ & 160 & 2000 & 1 & 0 & 4 & 0 & 0 \\
\hline $98-080$ & 145 & & & 0 & & & \\
\hline $98-081$ & $\begin{array}{l}130(1) \\
165(2)\end{array}$ & & & 0 & & & \\
\hline $98-082$ & $\begin{array}{l}130(1) \\
160(2) \\
210(3)\end{array}$ & 1000 & 1 & 0 & 3 & 0 & 0 \\
\hline $98-083$ & $\begin{array}{l}115(1) \\
140(2)\end{array}$ & 2000 & 2 & 0 & 5 & 0 & 0 \\
\hline $98-084$ & $130(1)$ & 2000 & 2 & 0 & 6 & 1 & 0 \\
\hline $98-085$ & 150 & 2000 & 1 & 0 & 3 & 0 & \\
\hline $98-086$ & & None & & 0 & abundant & 0 & 1 \\
\hline $98-087$ & & 10000 & 6 & 0 & 150 & 0 & 0 \\
\hline $98-088$ & $\begin{array}{l}130(1) \\
155(2)\end{array}$ & None & rare & 0 & abundant & 0 & 0 \\
\hline $98-089$ & 155 & 2000 & 1 & 0 & 38 & 0 & 0 \\
\hline $98-090$ & & None & 0 & 0 & abundant & 0 & 0 \\
\hline $98-091$ & 160 & None & & 0 & abundant & 0 & 1 \\
\hline $98-092$ & 155 & 1000 & 6 & 0 & 42 & 0 & 0 \\
\hline $98-093$ & 158 & 2000 & 2 & 0 & 12 & 0 & 0 \\
\hline $98-094$ & 165 & 500 & 2 & 0 & 8 & 0 & 0 \\
\hline $98-095$ & 180 & 10000 & 16 & 0 & 53 & 0 & 0 \\
\hline 98-096 & & 5000 & 4 & 0 & 22 & 0 & 0 \\
\hline Total & & 39500 & 44 & 0 & 346 & 1 & 2 \\
\hline
\end{tabular}


toward $100^{\circ}$, from a position west of Chibougamau. It is the most convincing evidence for a former ice divide oriented NE-SW or N-S, and located to the west of the Chibougamau area (as the proposed Mistassini ice divide of Dyke and Prest (1987), obtained during this study. If the same transport direction $\left(100^{\circ}\right)$ is applied to the Papaskwasati Formation, sandstone erratics derived from it could not have reached the Pipmuacan Reservoir area. If some of the sandstone erratics found in the Pipmuacan area are from the Papaskwasati Formation, which is probably the case, it implies that the Chibougamau Formation erratics were transported in the Pipmuacan area first, when the divide was oriented roughly $\mathrm{N}-\mathrm{S}$, to the west of Chibougamau; the Papaskwasati erratics were transported later, following the clockwise shift of the divide to a NE-SW position. Given the glacial lineation north of the reservoir (Fig. 11), it is highly probable that sandstone clasts from the Otish Supergroup, $300 \mathrm{~km}$ away, are also present in the Pipmuacan Reservoir area.

\section{THE MANOUANE RESERVOIR}

\section{AND AREA NORTH OF LAKE SAINT-JEAN}

Inspection of outcrops and borrow pits along the road from Saint-Ludger-de-Milot to Chute-des-Passes was done in early November 1999, and the road north of Chute-des-Passes and the shoreline of Manouane Reservoir in late summer 2003 (Fig. 2). Access by logging road to the reservoir, owned by Alcan, is possible only since 2001. It is located about $120 \mathrm{~km}$ to the southeast of Lake Mistassini, was flooded in 1941 and covers an area of $461 \mathrm{~km}^{2}$ (Fig. 2). The Commission de toponymie du Québec (1996) refers to the reservoir as Lake Manouane, but the term reservoir is used here to distinguish it from another Lake Manouane, located west of La Tuque, and also investigated in this study (see section on Lake Manouane-Lake Kempt). Deep, large, bays and numerous islands are characteristic of the shoreline which is carved mostly in till, but bedrock outcrops of Archean gneiss are numerous and wave-washed, bouldery lags from esker deposits, occur in places. This reservoir occupies a strategic position relative to the dispersal of erratics both from rocks of the Mistassini Group and from the Otish Supergroup. At the time of the visit, water level was about $4 \mathrm{~m}$ below the normal level for the time of year, thus creating high quality bedrock and bouldery till exposures for striations and clast counts. About half of the $450 \mathrm{~km}$ shoreline was searched for erratics and striated sites.

Striations were measured at 7 sites (Fig. 6; Table III), 4 of which show strong evidence of shifting ice flows from an early east-southeastward $\left(100^{\circ}\right.$ or more) direction to a last south-southeastward $\left(160^{\circ}\right.$ or more) along the shoreline and along the road south of Chute-des-Passes. A wide variety of sandstone and conglomerate erratics were found along the shoreline of the reservoir (Fig. 13). They are more abundant in the eastern part (stop 03-007 and higher) of the 30-km wide (east-west) reservoir than in the western part (Table III). Excluding the results of stop 03-002 (less reliable due to probable errors in count estimates), sandstone erratics form $11.8 \%$ of all clasts counted. Several sites show proportions in the vicinity of $25 \%$. The source rocks, either the Cheno and

\section{TABLE III}

Striations and clast count along Manouane Reservoir shoreline and surroundings

\begin{tabular}{|c|c|c|c|c|}
\hline $\begin{array}{l}\text { Stop } \\
\text { number }\end{array}$ & $\begin{array}{c}\text { Striations } \\
\text { Azimuth }\left({ }^{\circ}\right)\end{array}$ & $\begin{array}{l}\text { Clast } \\
\text { count }\end{array}$ & $\begin{array}{l}\text { Papaskwasati } \\
\text { or Indicator } \\
\text { Group sandstone }\end{array}$ & $\begin{array}{c}\text { Iron } \\
\text { formation }\end{array}$ \\
\hline 03-002 & 158 & 50000 & 40 & 7 \\
\hline 03-003 & & 2000 & 4 & \\
\hline 03-005 & & 2000 & 8 & \\
\hline 03-007 & 174 & 1000 & 160 & \\
\hline 03-008 & & 700 & 80 & \\
\hline 03-009 & & 2000 & 400 & \\
\hline 03-010 & $\begin{array}{c}90(1) \\
170(2)\end{array}$ & 1000 & 200 & \\
\hline 03-012 & & 300 & 80 & \\
\hline 03-015 & & 500 & 120 & \\
\hline 03-016 & $\begin{array}{l}100(1) \\
160(2)\end{array}$ & & & \\
\hline 03-017 & $\begin{array}{l}135(1) \\
160(2)\end{array}$ & & & \\
\hline 03-019 & $\begin{array}{l}120(1) \\
140(2) \\
170(3) \\
190(4)\end{array}$ & 500 & 130 & \\
\hline Total & & 60000 & 1182 & 7 \\
\hline
\end{tabular}

Papakwasati formations or rocks from the Otish Supergroup are located more than $100 \mathrm{~km}$ and $120 \mathrm{~km}$, respectively from the northern shore of the reservoir. The presence of black sandstone clasts (possibly from the Cheno Formation) suggest that the erratics of the Manouane Reservoir may include some Papaskwasati clasts brought in by earlier eastward ice movements. Both Papaskwasati sandstone and dolostone clasts were found along the $250-\mathrm{km}$ road joining the reservoir to Saint-Ludger-de Milot, but no dolostone clasts were noted north of Chutes-des-Passes (Fig. 7).

The absence of Albanel dolostone erratics around the reservoir argues for a dominant provenance from the Otish Supergroup, i.e. down-ice from the last major ice flow as shown on the glacial lineation map (Fig. 11). It seems unlikely that the former east-southeastward direction of flow observed in striations was sustained for a long period, because if it had been, dolostones from the Albanel Formation would be present along the shoreline, and none were observed. A strong association was noted everywhere in the study area between the distribution of Albanel clasts and sandstone clasts from the Cheno and Papaskwasati formations. Dolostone erratics occur everywhere south of a line $\left(130^{\circ}\right)$ drawn between the northern shore of Pipmuacan Reservoir and the contact between the Albanel and Cheno formations (Fig. 11).

\section{EVOLUTION OF ICE DISPERSAL CENTRES}

The ice-flow and glacial transport data described to this point illustrate clearly that at least two major and widespread 


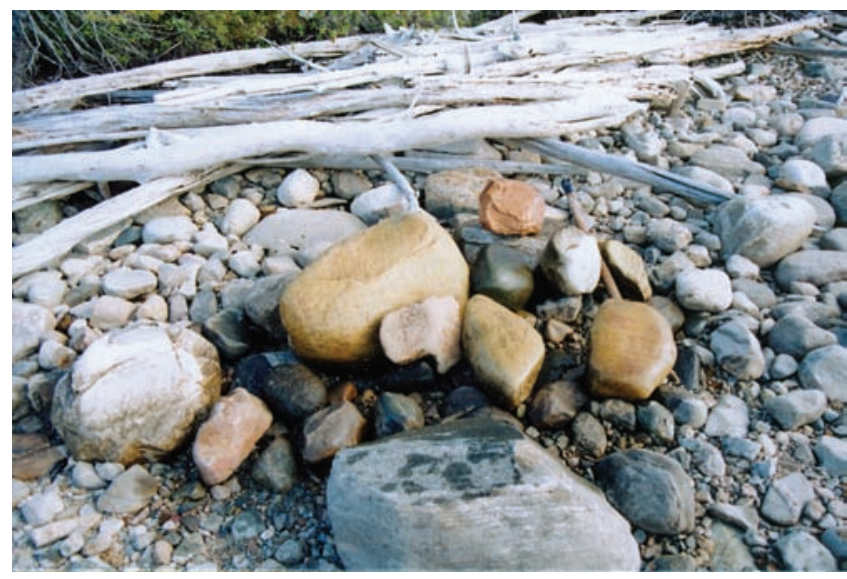

FIGURE 13. Wide variety of sandstone erratics, most likely from the Otish Supergroup, found along the shoreline of Manouane Reservoir.

Erratiques de grès variés, probablement en provenance du Supergroupe d'Otish, trouvés sur les rives du réservoir Manouane.

ice-flow events, both major carriers of glacial debris, occurred at different times in the central part of Grenville province (Fig. 14). Little reference was made to the widespread, northwestward, and oldest ice flow toward Hudson Bay, for which evidence was found in, and to the north of the Chibougamau area (Veillette and Pomares, 1991; Veillette, 1995; Paradis and Boisvert, 1995). It is now correlated with the distribution of specific erratics mapped during this project and that of erratics known from earlier, unpublished work by the author north of $50{ }^{\circ} \mathrm{N}$, to reconstruct a sequence of shifting ice flows that involves three major vectors of ice movement.

\section{ERRATICS FROM THE CHIBOUGAMAU FORMATION}

Erratics from the Chibougamau Formation are found between azimuths $97^{\circ}$ and $260^{\circ}$, a range of $163^{\circ}$ (Fig. 15). Assuming a provenance from the northernmost part of the formation, the presence of these erratics north of Lake Waswanipi, requires a direction of ice movement toward $260^{\circ}$, and a provenance from the southern part of the formation a direction toward $270^{\circ}$. Thus, the last, southwestward $\left(215^{\circ} \pm 10^{\circ}\right)$ ice flow (Fig. 14) cannot explain their presence at this location. A westward to northwestward ice movement, is required to transport Chibougamau Formation erratics to the area north of Lake Waswanipi. The southwestward deglaciation ice flow adequately explains glacial transport in the Gouin Reservoir area. In the Tadoussac and Pipmuacan Reservoir areas, Chibougamau Formation erratics, had to be brought in by the former southeastward $\left(120^{\circ}-130^{\circ}\right)$ and nearly eastward $\left(100^{\circ}\right)$ ice flows, respectively.

\section{STROMATOLITIC DOLOSTONE ERRATICS}

The distribution of clasts of stromatolitic dolostone is less helpful than that of clasts from the Chibougamau Formation for defining westward or northwestward glacial transport (Fig. 16). This type of Mistassini erratic is rare and source areas are scattered over the whole length of Lake Mistassini basin (see Fig. 5). Their distribution shows that both the early southeastward and younger southwestward and southward ice flows could have transported these erratics. Dionne (Dionne, 1994; Dionne, personal communication, 2006) reports clasts of stromatolitic dolostones at several locations in the Saguenay corridor, and Govare (1995) in the La Malbaie area (Fig. 16). The presence of a wide variety of Mistassini erratics on both the north and south shores of the St. Lawrence estuary, up to Cap Colombier $150 \mathrm{~km}$ to the northeast of Tadoussac (the most northeastern site along the north shore where stromatolitic and other dolostones were found), argues for a glacier tongue in the Saguenay fjord calving into Goldthwait Sea (Dionne, 2001).

\section{DOLOSTONE ERRATICS FROM THE ALBANEL FORMATION}

Dolostone clasts found north of $50{ }^{\circ} \mathrm{N}$, in the Lake Evans and Nemiscau areas during field work carried out in the early 1990s, imply northwestward transport from the Lake Mistassini area, and those found in the Pipmuacan Reservoir area southeastward transport (Fig. 17). All clasts were found in till. The $140^{\circ}$ range between the $265^{\circ}$ and $125^{\circ}$ confining azimuths is a minimum value, since the source area for the dolostone fragments is here conservatively assumed to be the northernmost part of the Albanel Formation. A provenance from the central or southernmost part of the Albanel Formation, which is likely the case for some erratics, would indicate that the northwestward ice flow was opposite to the southeastward ice flow, a situation supported by the striation record.

\section{SANDSTONE ERRATICS FROM THE PAPASKWASATI FORMATION AND FROM THE OTISH SUPERGROUP}

Erratics from these two source areas lie entirely within the range of the former southeastward and the later southwestward ice flows described earlier (Fig. 18). Field investigation was not carried far enough directly north of Lake Mistassini to detect long-distance, possible westward or northwestward transport of Papaskwasati erratics. It would be necessary to examine the shoreline of large water bodies north of Nemiscau to verify this possibility. With the data now available, the distribution of these erratics is limited to the interaction of the two glacial transport directions shown on Fig. 14.

\section{SEQUENCE OF ICE FLOWS}

The ice-flow relative chronology and glacial transport data schematically shown in Figure 19 is summarized as follows: (1) flow 1 was a widespread ice movement toward the northwest from a dispersal centre in the Québec highlands, south of Lake Mistassini and north of St. Lawrence River Valley, (2) flow 2 was toward the southeast, from a NE-SW ice divide that migrated from the Québec highlands to the north of Lake Mistassini, and (3) fan-shaped flow 3, toward the southwest, south and southeast, formed during deglaciation, as depicted in Figure 11 based on the Glacial Map of Canada (Prest et al., 1968). The zone separating earlier flows 1 and 2 that is parallel to the longitudinal axis of Lake Mistassini, does not represent an ice divide position. Rather, it marks the southern limit of 


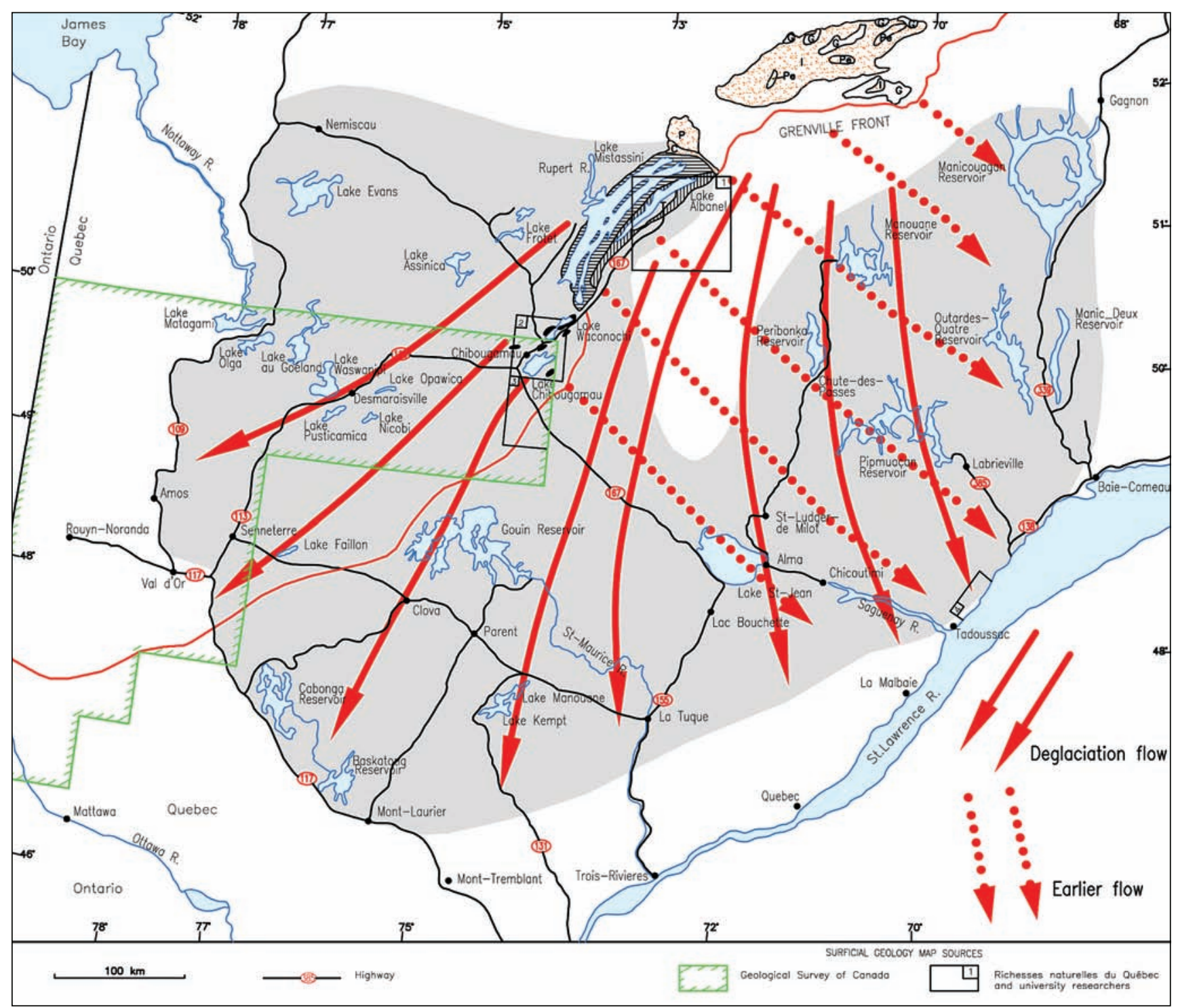

FIGURE 14. Sequence of ice flows and dispersal of Mistassini rocks in south-central Québec, north of St. Lawrence River Valley. The earlier flow, toward the east-southeast, carried Mistassini rock fragments more than $400 \mathrm{~km}$, and the deglaciation flow, predominantly toward the southwest, more than $500 \mathrm{~km}$. See Figure 5 for the legend of the Mistassini rocks.

northwestward striations (earlier flow 1) and the northern limit of southeastward striations (earlier flow 2). North of this zone, outcrops bear well-developed cross-striated facets indicating a first west-northwestward $\left(280^{\circ}-310^{\circ}\right)$ ice movement that extend into James Bay (Veillette, 1995), crossed by a later one toward the southwest $\left(200^{\circ}-215^{\circ}\right)$, a counterclockwise shift in ice flows. South of it, in the Chibougamau-Lake Mistassini area and in the large part of Grenville Province covered by this study, the sequence is reversed; southeastward striated facets $\left(105^{\circ}-130^{\circ}\right)$ are overprinted by marks from the same deglaciation flow $\left(200^{\circ}-215^{\circ}\right)$ as north of it, thus defining a clockwise shift in ice flows.

The dispersal of Albanel Formation dolostones to the northwest of Lake Mistassini (Fig. 17), implies a dispersal centre
Séquence d'écoulement et de dispersion glaciaires des erratiques de Mistassini, dans le centre-sud du Québec, au nord de la vallée du SaintLaurent. L'écoulement ancien, vers le sud-est, a transporté les erratiques de Mistassini sur des distances de plus de $400 \mathrm{~km}$, et celui formé lors de la déglaciation, de direction dominante vers le sud-ouest, sur plus de $500 \mathrm{~km}$. Voir la figure 5 pour la légende des roches de Mistassini.

located south of the lake and striations indicating northwestward movement. Cross-striated outcrops bearing marks of northwestward moving ice, south of the Chibougamau-Lake Mistassini area have never been reported. This may be attributed to the destruction of these early marks by the erosive action of the two major subsequent ice flows. Alternatively, striations from earlier flow 1 could have escaped detection by earlier investigators, since erosional features left by ice flowing toward the northwest were not expected to be present in the general area until recently (Veillette and Pomares, 1991). A third possibility may be related to the presence of cold base ice during glacier inception in the Québec highlands; warm base flow may have been initiated only in the vicinity of Lake Mistassini as the glacier expanded toward the northwest. 


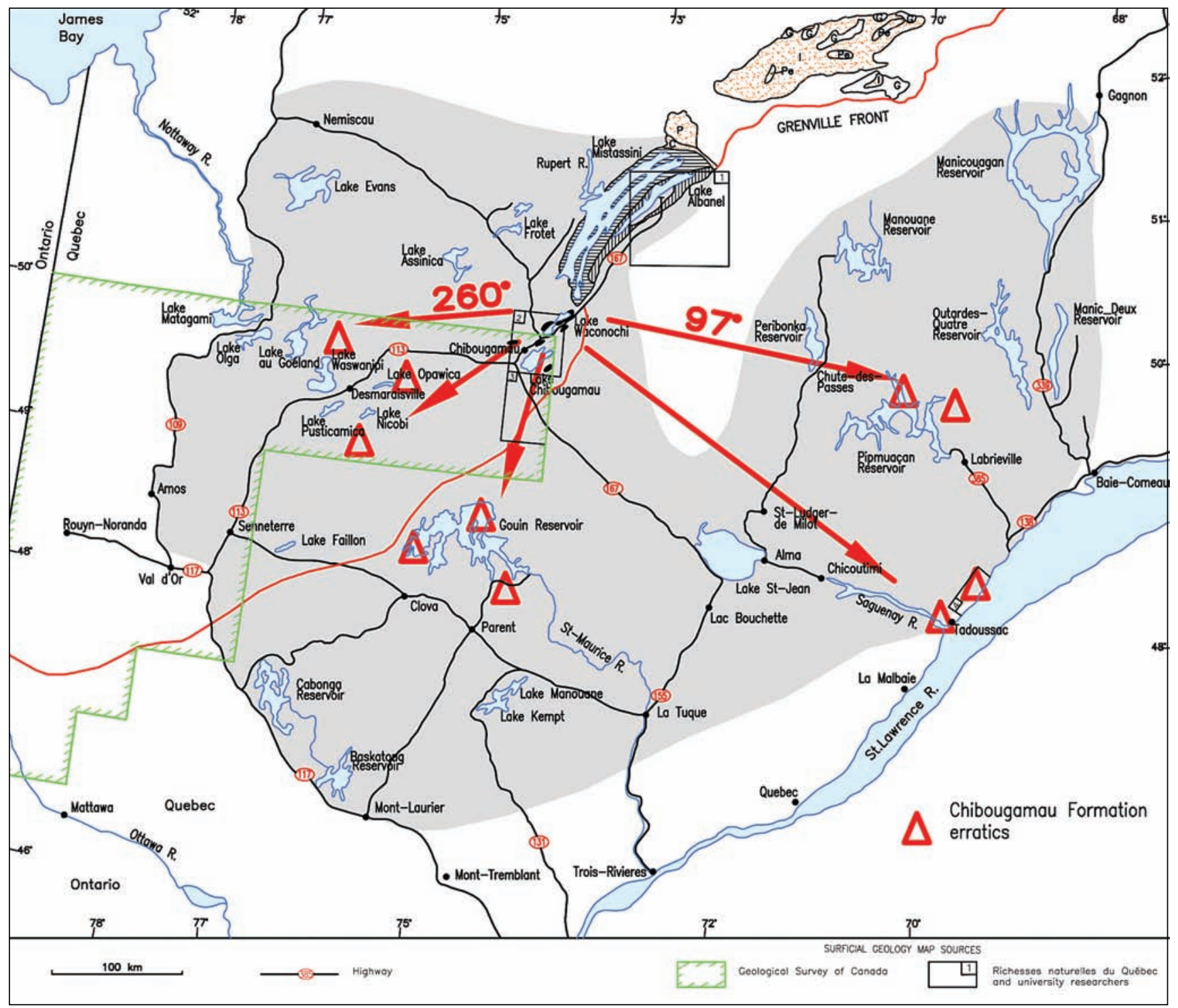

FIGURE 15. Dispersal of erratics from the Chibougamau Formation.

Répartition des erratiques de la Formation de Chibougamau.

Whatever the reason for the lack of reported evidence for earlier flow 1 striations within the domain of flow 2, the glacial transport data justify the need for a meticulous search for outcrops that could bear them within the large area dominated by flow 2 toward the southeast (Fig. 19). These striations, will be difficult to detect, because earlier flows 1 and 2 have basically the same orientation but opposite directions. It is also probable that the upper surfaces of most outcrops that once bore flow 1 striations were eroded by flow 2 or flow 3 or by both, thus leaving a gap in the striation record. A spectacular outcrop located along the Chibougamau-Nemiscau road, suggests, however, that field evidence for the 3 major ice movements shown on Figure 19 may be present, locally. The site, a large outcrop exposed by the removal of the till cover during construction of the road in 1993 was first visited then, and revisited in 1999 (Veillette, 1995). It is located about $40 \mathrm{~km}$ north of Chibougamau and bears erosional marks from three different events: (1) a widespread, upper, striated surface indicates ice movement toward $220^{\circ}$, (2) on sheltered facets from this upper surface, older striations indicating moving ice toward $285^{\circ}$ near the base are truncated by (3) striations indicating movement toward $130^{\circ}$, near the top. Figure 20 shows the cross-cutting relationship between striations from (2) and (3). Outcrops showing the best potential for the preservation of this complex ice flow sequence will have to be carefully targeted to maximize chances of locating sites where the three generations of striations are preserved. A similar situation exists along the east coast of southern James Bay (Veillette, 1997). There, outcrops showing three intersecting striated facets, including those formed by two opposing ice flows, were correlated with widespread, regional, ice-flow events.

Transport of Mistassini erratics toward the west and northwest is demonstrated here for the first time in the ChibougamauLake Mistassini area. This direction of ice flow was overlooked 


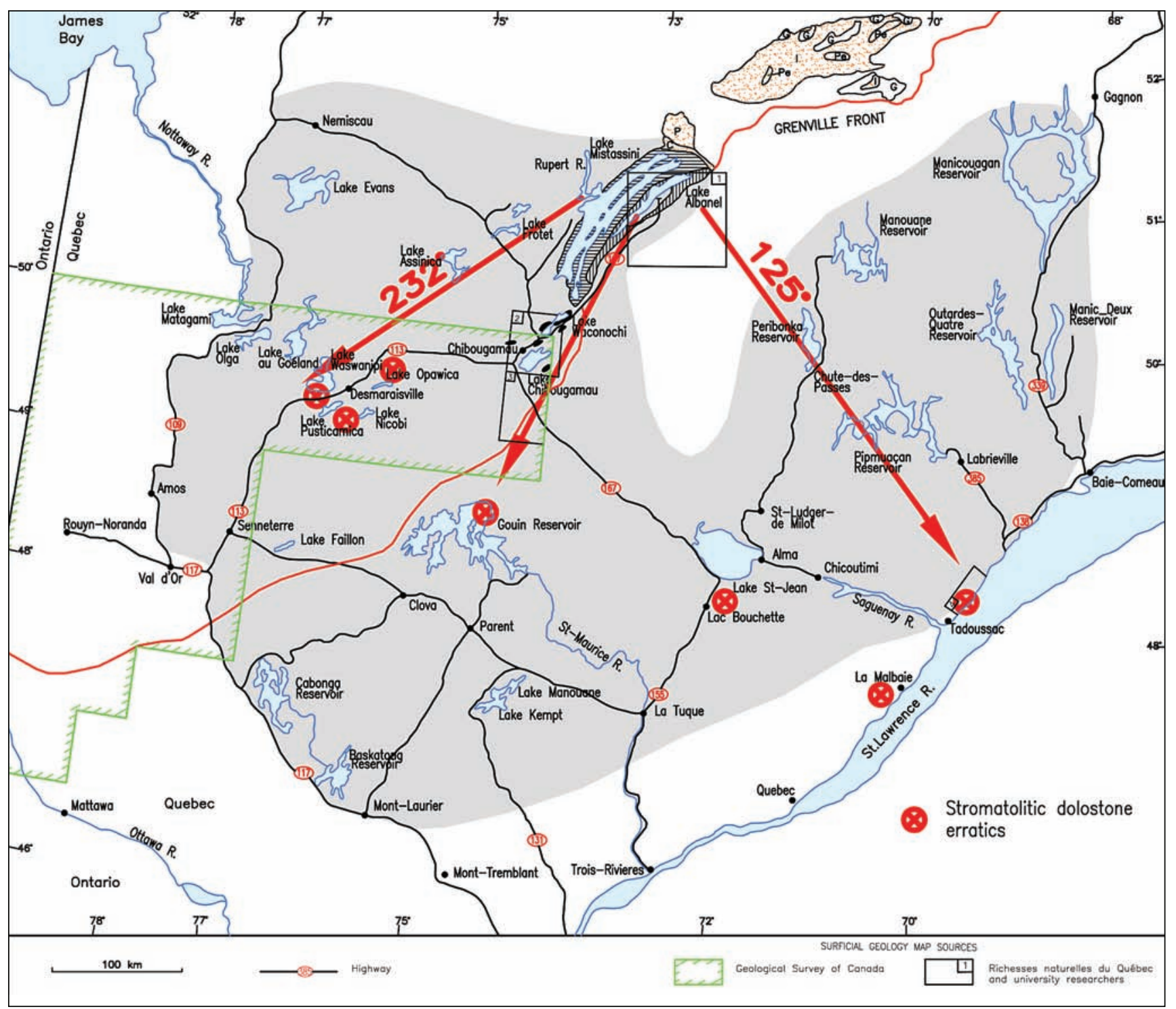

FIGURE 16. Dispersal of stromatolitic dolostone erratics from the Albanel Formation.

in previous work in the area because it was assumed that the oldest ice flow was toward the southeast. Sampling grids were laid out to intercept transported clasts toward the southeast and the southwest only, with no coverage to the north and to the northwest of the source rocks (De Corta, 1988; Beaudry, 1994; Levasseur and Prichonnet, 1995).

\section{INCEPTION OF THE LABRADOR SECTOR OF THE LAURENTIDE ICE SHEET}

The hypothesis of glacier inception into the interior of Québec, with subsequent expansion toward the northwest (Hudson Bay) is not new. Low (1903) proposed that the oldest facet bearing northwestward striations, of 3 different striated facets found on the same outcrop, along the east coast of James Bay and Hudson Bay, were formed by the expansion
Répartition des erratiques de dolomie à stromatolites de la Formation d'Albanel.

of a glacier from a "gathering ground" located between $50{ }^{\circ} \mathrm{N}$ and $51^{\circ} \mathrm{N}$ in Québec. The second oldest set of striated facets, indicative of flow toward the west-southwest, was taken as an indication that the ice divide that formed the oldest set had migrated northward, beyond $54{ }^{\circ} \mathrm{N}$, while the latest set of striated facets indicative of movement toward the south-southwest, was interpreted as the continuation of the previous shift in ice flow. While Low could not provide a detailed configuration of the ice mass, his interpretation of the shifting centres of dispersion, derived from striation measurements taken along the coast only, is most remarkable, because the proposed locations of his ice divides correspond to positions south of Lake Mistassini for the oldest northwestward ice flow, and north of the lake for the second oldest west-southwestward ice flow, as proposed in the present paper. This chronology of striated surfaces and associated glacial transport was throrougly validated 


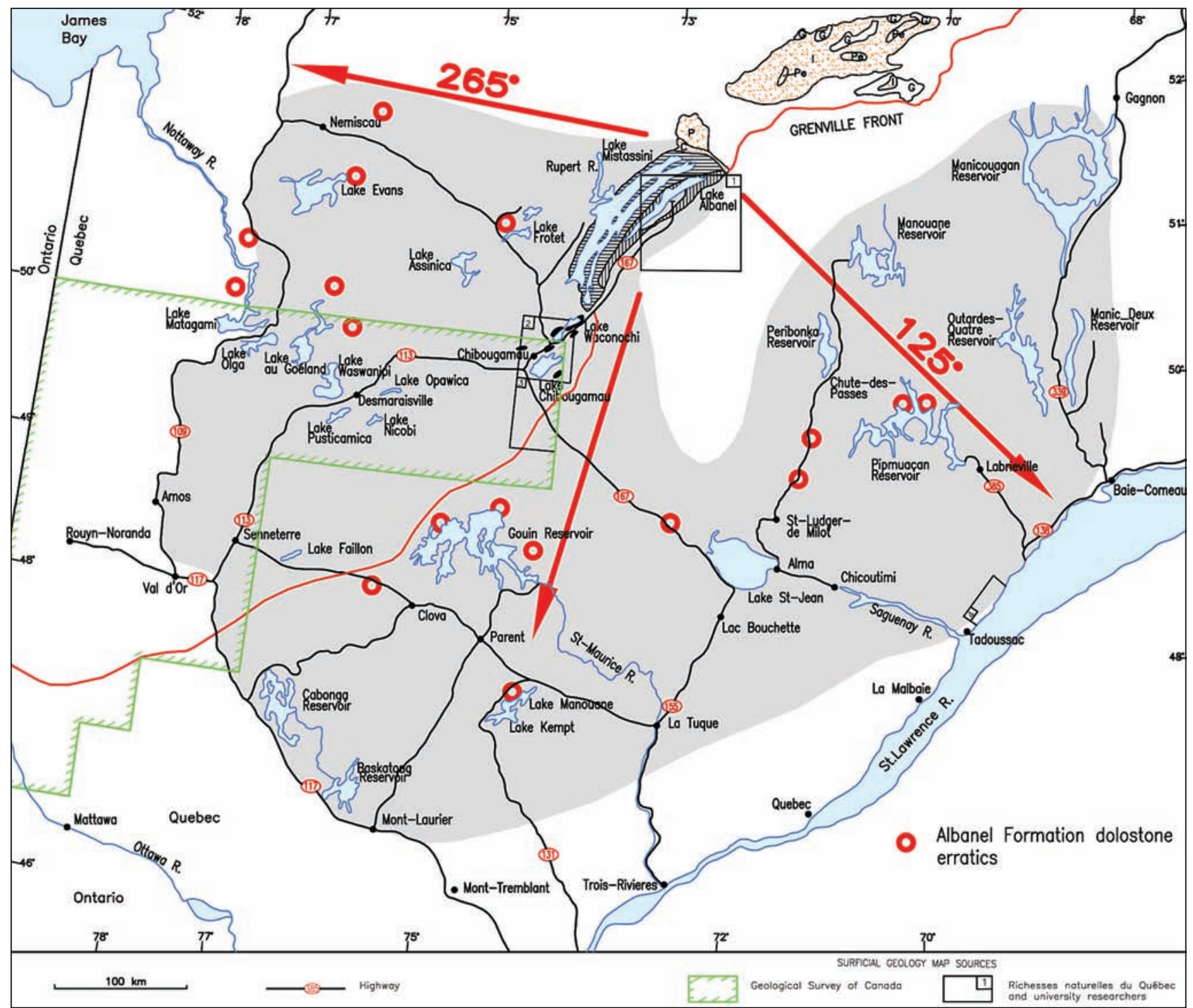

FIGURE 17. Dispersal of dolostone erratics from the Albanel Répartition des erratiques de dolomie de la Formation d'Albanel. Formation.

along the James Bay eastern coast and inland as far east as Matagami and Chibougamau (Veillette and Pomares, 1991; Veillette, 1995, 1997; Veillette and Roy, 1995; Parent et al., 1996). Low's insightful interpretation was overlooked by glacial geoscientists for nearly a century. Flint (1943) acknowledged that Low's analysis of the James Bay cross-striated surfaces demonstrated that some shifting of ice masses occurred, but rejected the association of the oldest striations with the glacier expansion phase.

Glacier inception in the Quebéc highlands (Fig. 21), was later proposed by Flint (1947: p. 232) “... the Labradorian center (lying more in Québec than in Labrador) is believed to have been the area of origin of a separate ice sheet which by coalescence with glaciers flowing outward from other highlands in Eastern North America formed the Laurentide Ice Sheet". The hypothesis of highland origin and windward growth, first pro- posed by Upham (1895) to explain the westward expansion of North American ice sheets, was applied by Flint $(1943,1947)$ to the Laurentide Ice Sheet. The hypothesis contends that the LIS was immigrant into the greater part of the vast region it covered. Valley glaciers in the Québec and Labrador highlands coalesced into piedmont glaciers and united into a single ice cover that, nourished by snowfall from warmer, moist, air masses moving across the continent from the south and west, expanded westward. Occhietti (1982) proposed that ice remained in the Manicouagan plateau throughout the Wisconsinan. Acceptance of the Québec highlands as a major inception centre for the last ice sheet implies finding additional physical evidence than that presented in this paper to determine the location of the very first centres of growth, north of St. Lawrence River Valley. The data presented here, however, when considered with climatological records for the area, 


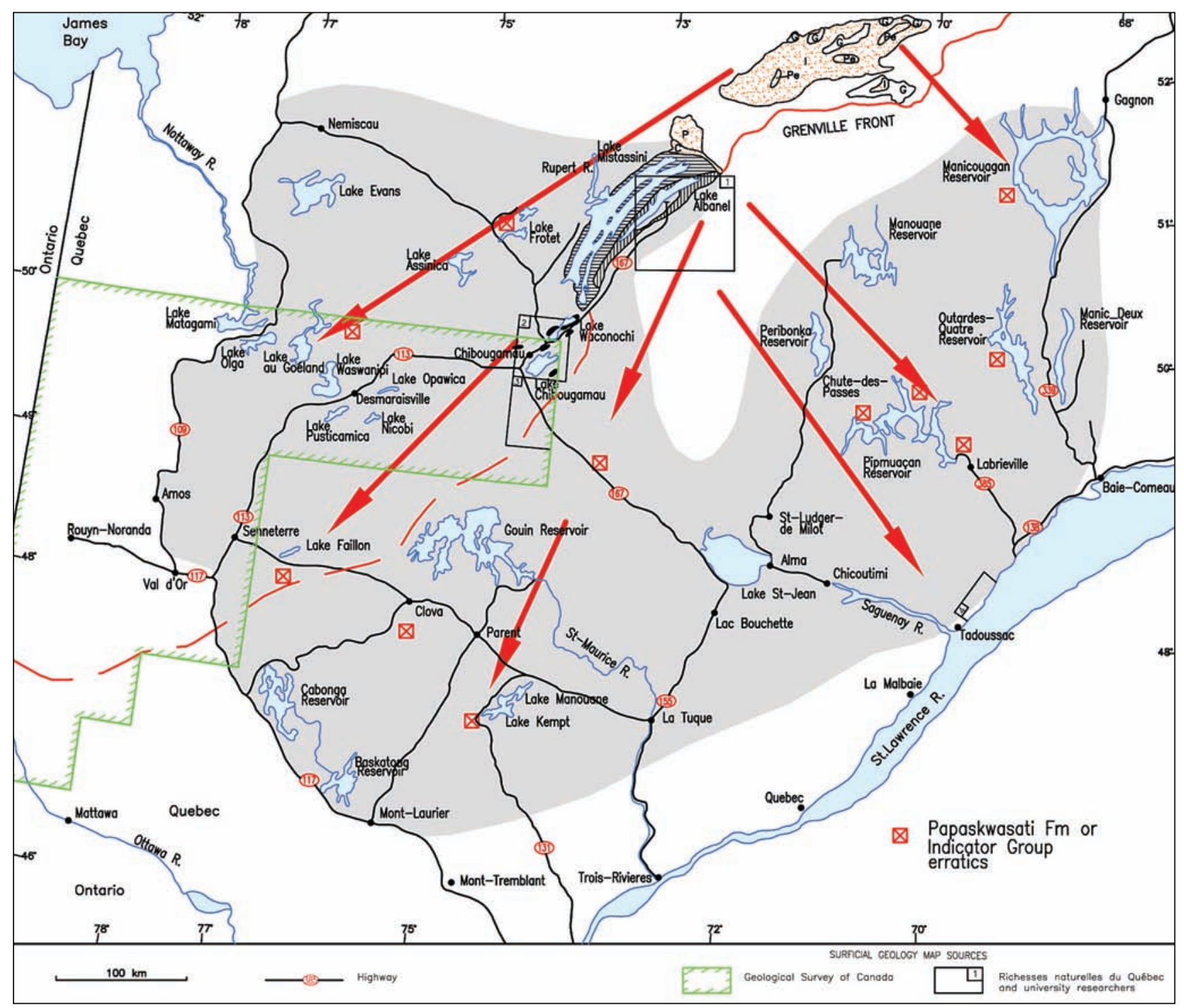

FIGURE 18. Dispersal of sandstone erratics from the Papaskwasati Formation and the Otish Supergroup.

argue for a major zone of glacier inception north of St. Lawrence River Valley but to the south of Lake Mistassini. The search for relict northwestward striations and lithological indicators of glacial transport toward the northwest, even if seriously impaired by the erosive action of subsequent ice flows, is underway, south of Lake Mistassini.

Contemporary mean annual precipitation, number of days with measurable precipitation, snowfall, and maximum snow depth for Québec-Labrador suggest that climatic conditions approach those required for glacier inception in the Québec highlands (Fig. 22). Assuming that annual precipitation patterns during the last ice-free periods were similar to contemporary ones, initial growth would have started in a narrow fringe north of the river, close to the source of available moisture. Northwestward expansion of the ice sheet would then result from snow accumulation on the gently sloping surface
Répartition des erratiques de grès de la Formation de Papaskwasati et du Supergroupe d'Otish.

that extends from the highlands to Hudson Bay and beyond. The striation record and glacial transport data now available, appear to be compatible with the windward growth model.

\section{DISCUSSION}

Cross-striations as a tool to infer the direction of former ice flows and idenfify the main sectors of the Laurentide Ice Sheet were used with success by pionner geologists of the Geological Survey of Canada. Subsequent generations of field Quaternary scientists made a highly variable use of this tool, ranging from rejection to occasional use. Flint rejected the correlation between the oldest striations and glacier expansion proposed by Low (1903) in James Bay, and chose instead to consider the intersecting striations as the product of shifts during late deglaciation. (Flint, 1943: p. 330) "It is generally 


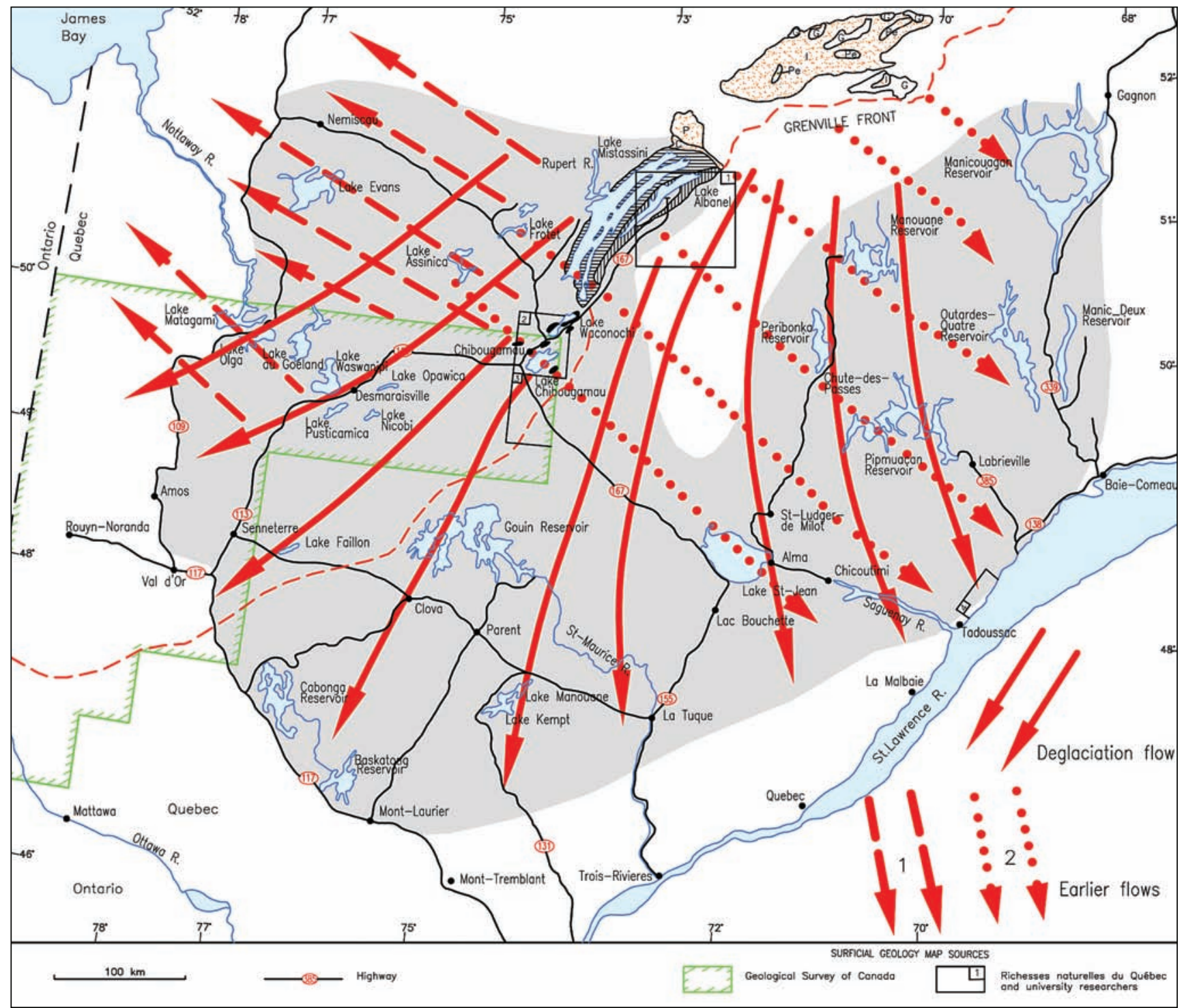

FIGURE 19. Sequence of ice flows between the St. Lawrence River Valley and James Bay showing the zone separating the two former opposing ice flows overprinted by the glacial lineation developed during the last ice retreat.

conceded that all but a specific few of the striae concerned were made very late indeed and probably very late in the Wisconsinan age, for any striae recording earlier directions of flow would have been crossed or erased by striae made during the episode of latest flow". He acknowledged, however, that multiple sets of striae, provided useful information to reconstruct windward growth of the LIS, but deplored the fact that it was still very scanty (Flint, 1943). This dismissal by a highly reputable Quaternary geologist, may explain why Low's interpretation, which is now relevant to the understanding of the evolution of the Labrador Sector of the LIS, was disregarded for so long.

The assumption that striations formed by earlier ice flows were destroyed by subsequent ice flows, to the point that they are not useful to the reconstruction of former, older ice flows,
Séquence d'écoulements glaciaires entre la vallée du Saint-Laurent et la baie de James; la zone de démarcation entre les deux écoulements anciens, de sens opposé, est recoupée par la linéation glaciaire formée durant le dernier retrait glaciaire.

is not supported by the results presented here, nor by field observations elsewhere on the Canadian Shield. Most iceflow studies cited in this paper, carried out at various locations on the Shield, present compelling evidence that intersecting striations mapped systematically, grouped into classes of relative ages and correlated with glacial transport data, allow meaningfull reconstructions of former ice divide positions both within the Labrador (Klassen and Thompson, 1993; Veillette et al., 1999) and the Keewatin (McMartin and Henderson, this volume) sectors of the LIS. The hard, crystalline substrate of the Canadian Shield, where glacial erosion was generally less severe than in regions underlain by younger, less resistant, clastic or calcareous sedimentary rocks, contributed to the preservation of a longer striation record. The fact that most North American glacial geoscientists 


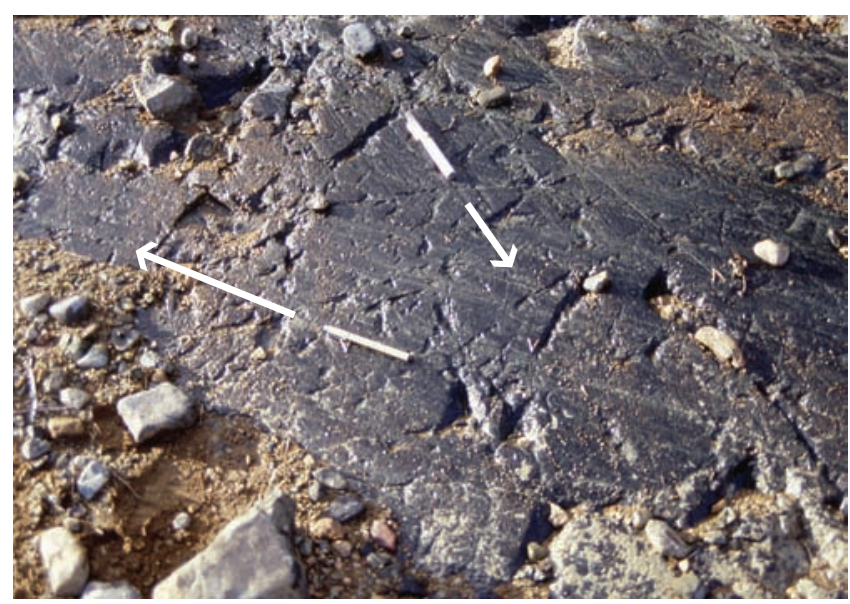

FIGURE 20. Striations from oldest ice flow 1 toward $285^{\circ}$ (large arrow), crossed by striations from ice flow 2 toward $130^{\circ}$ (small arrow).

Surface striée par l'écoulement le plus ancien no. 1 vers $285^{\circ}$ (grande flèche), recoupée par des stries du mouvement ancien no. 2 vers $130^{\circ}$ (petite flèche). were trained and practice in areas of thick drift, underlain by soft rocks (American Midwest, southern Ontario, Canadian Prairies, St. Lawrence Valley), where the use of striations is less relevant to the reconstruction of ice flows, may explain why many fail to realize the full potential of the method as a tool to reconstruct glacial history.

"A boulder has the indisputable advantage over finer till fractions in that it is always an undiluted sample of the source bedrock, irrespective of transport distance" (Puranen, 1988: p. 27). This statement is the basis for the glacial transport method used in this study. Salonen (1986) demonstrated that a small proportion of surface boulders in Finland, typically less than $10 \%$, have travelled very long distances. For ice-flow dynamics reconstructions involving palimpsest dispersal trains of far-traveled indicator clasts, as is the case here, presence or absence of indicators at a given site, is the first and most difficult concern to address, because of the required time-consuming searches. In areas located farthest from the source rocks, where indicator clasts are extremely rare, absence may result from inadequate sample or search area sizes, "absence of evidence is not evidence of absence" (Sagan, 1996: p. 213). Therefore, the maximum distances of transport recorded here, may be less than the true distances. Areal coverage, rather than the detailed reconstruction of clast abundance profiles

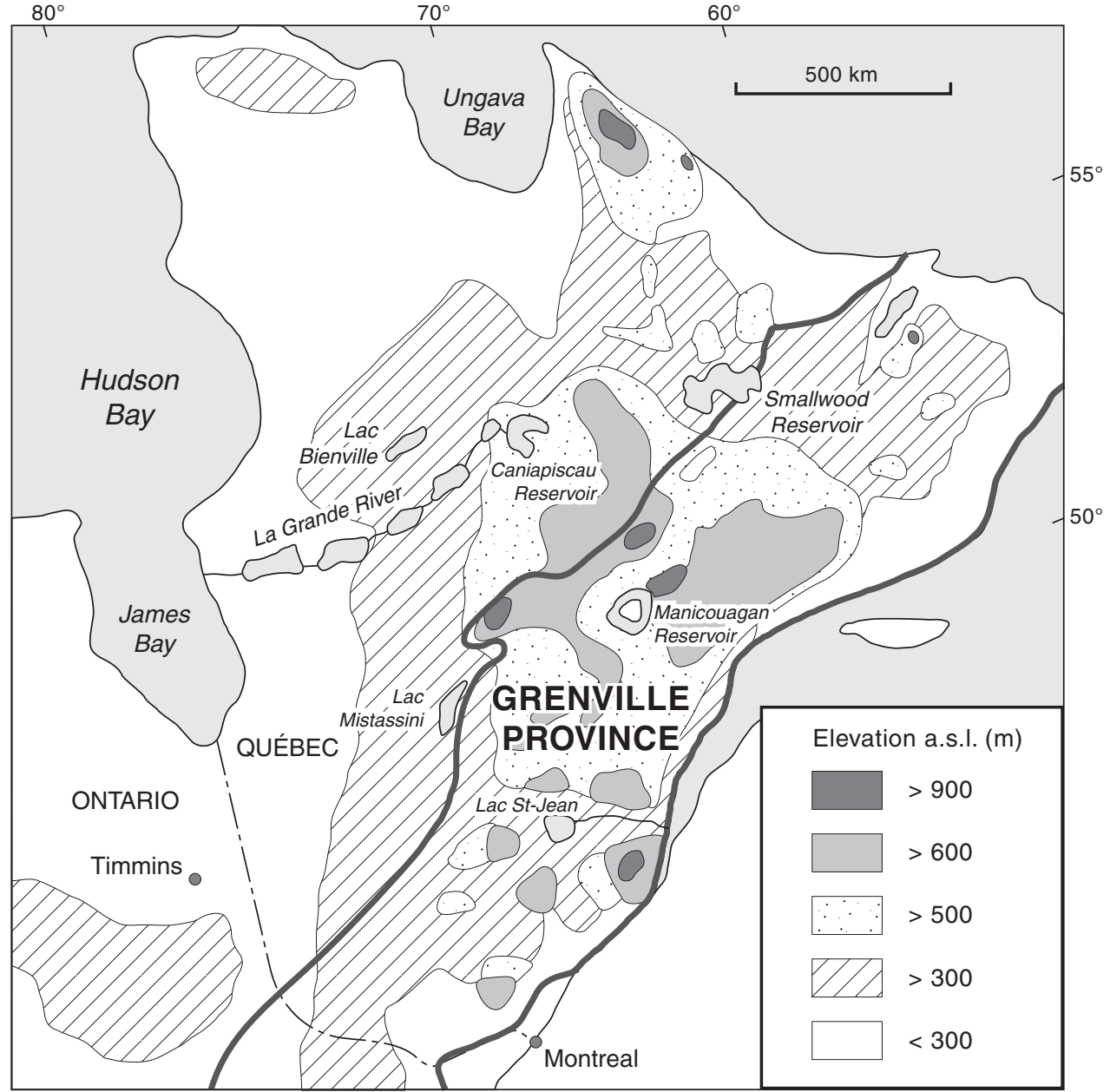

FIGURE 21. Elevation map of Québec, north of St. Lawrence River Valley, and of eastern Ontario and Labrador. Bold solid lines delineate the Grenville Province. The Québec highlands is defined here as the area above $500 \mathrm{~m}$. Adapted from the National Atlas of Canada (1973) and the Ministère de l'Énergie et des Ressources du Québec (1987).

Carte montrant les tranches d'altitude du Québec au nord de la vallée du Saint-Laurent, de l'est ontarien, et du Labrador. Les lignes en gras délimitent la province de Grenville. Les hautes-terres du Québec réfèrent ici à la région audessus de $500 \mathrm{~m}$. Adapté de l'Atlas géographique du Canada (1973) et du MInistère de l'Énergie et des Ressources du Québec (1987). 

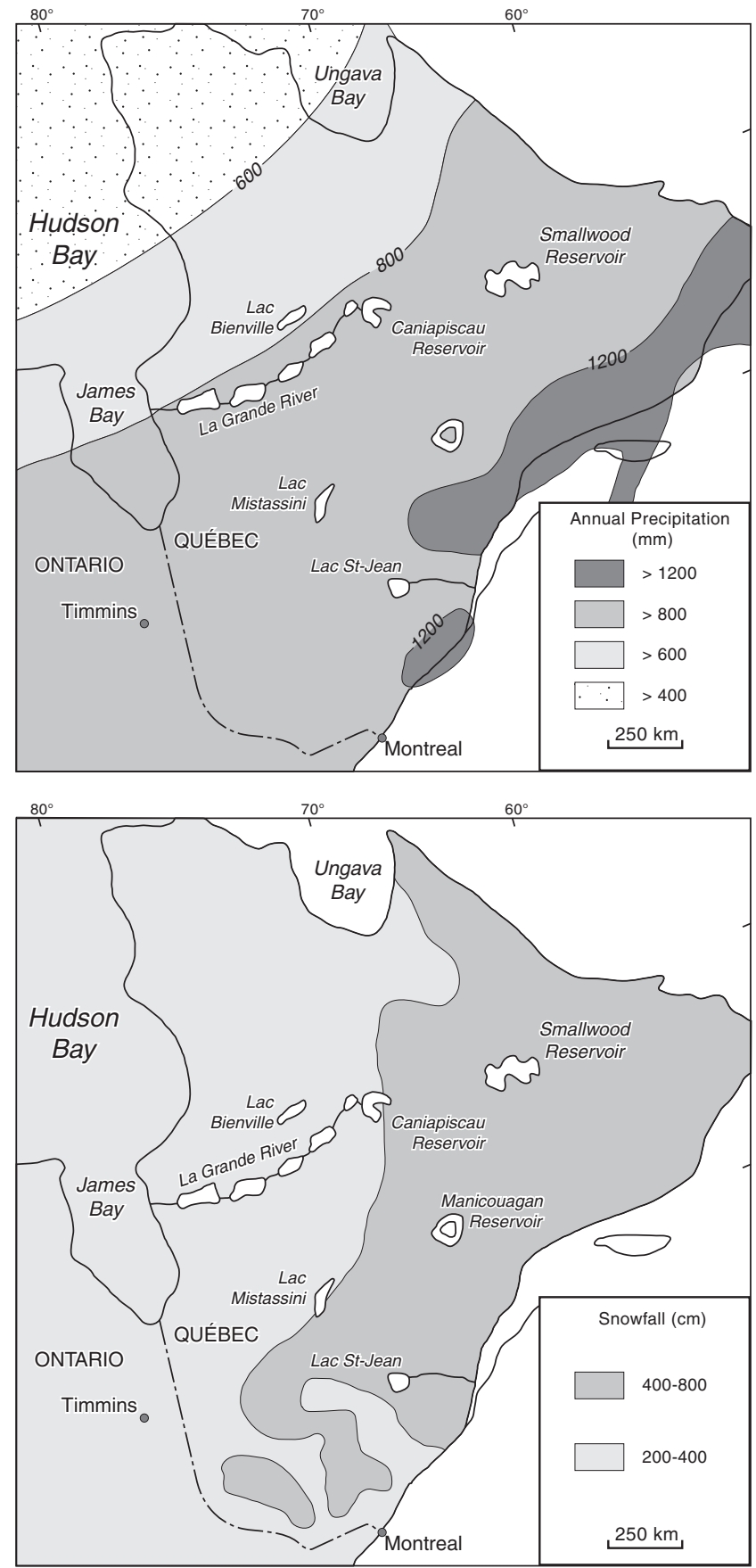

FIGURE 22. (A) Mean annual precipitation, (B) number of days with measurable precipitation, (C) thickness of snowfall, and (D) maximum snow depth for Québec Province, north of St. Lawrence River Valley, Labrador, and eastern Ontario. Adapted from the National Atlas of Canada (1991).

was essential to meet the objectives of this research. Clast sampling was performed almost entirely in the "tail" part of clast abundance profiles, in which the decrease in concentration is linear (Shilts, 1976).

It is, however, necessary to discuss some basic observations regarding the relative abundance of indicator clasts versus the distance travelled. Field observations indicate that this
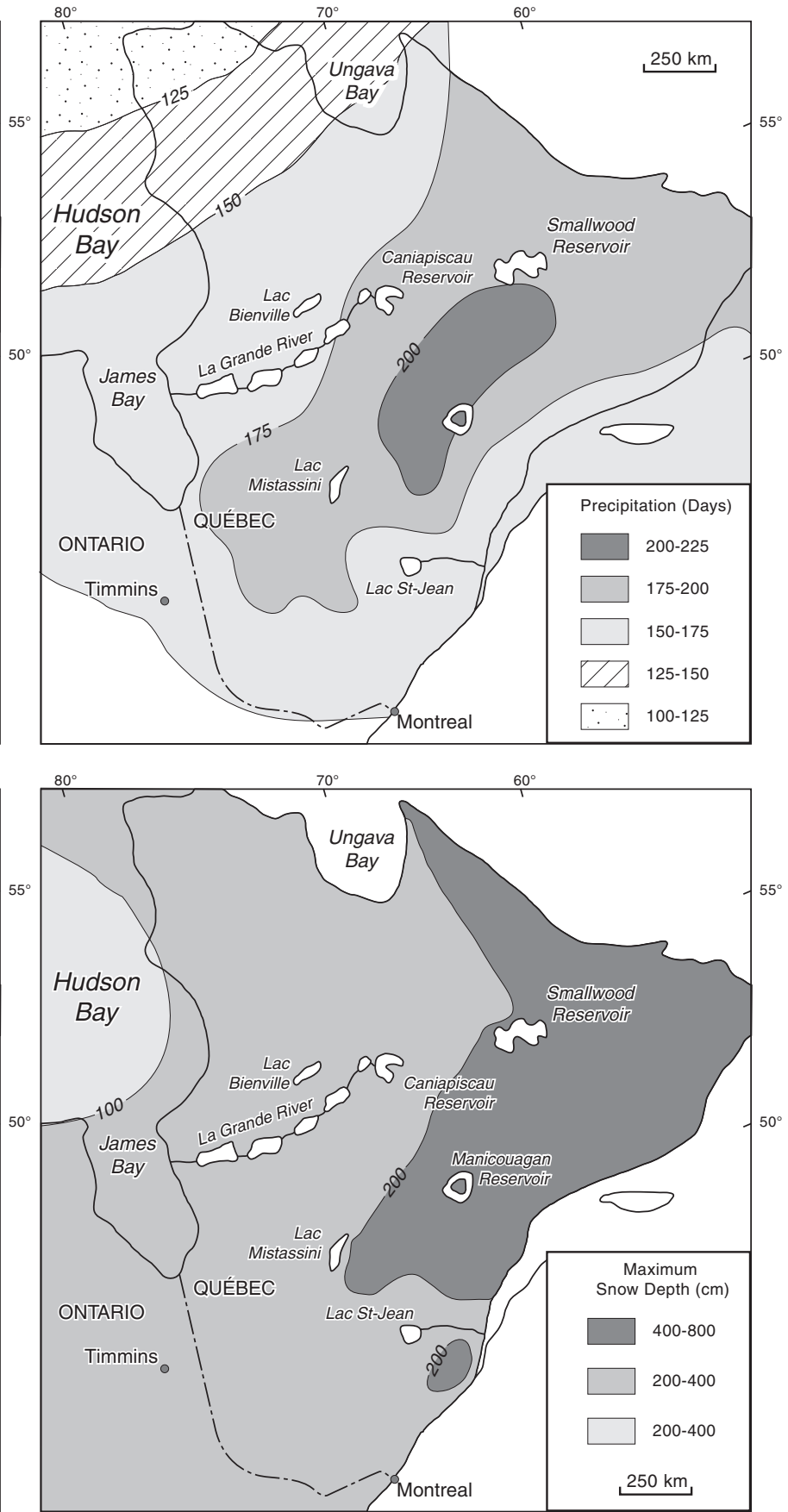

(A) Précipitations moyennes annuelles, (B) nombre de jours avec des précipitations mesurables, $(C)$ épaisseur de la couche de neige et (D) sa profondeur maximale pour la région au nord du Saint-Laurent, au Labrador et dans l'est ontarien. Adapté de l'Atlas de géographie du Canada (1991).

relationship must take into consideration the different lithologies of the Mistassini indicator clasts. Transport of a wide variety of Mistassini erratics in the Pipmuacan Reservoir area, along the Chute-des-Passes road, and along the St. Lawrence River Estuary, east of Tadoussac (Dionne, 1994; Dionne and Bernatchez, 2000) demonstrates that the east-southeastward ice flow (Fig. 6) that preceded the deglaciation ice flows 
(Fig. 11), was an effective agent of glacial transport over long distances. The belief that the boulder fraction reflects mainly the last or strongest flow, because during multi-stage glacial transport most of it is commituted to finer fractions as proposed by Mutanen (1971), may be misleading if lithology is not taken into account. The under representation of dolostone erratics compared with the sandstone erratics is obvious everywhere, in spite of larger areas of source rocks and shorter distances of transport for the dolostone erratics. The difference is particularly obvious in the Gouin Reservoir area where only flow 3 (the last deglaciation flow) could have carried the erratics. Therefore, resistance to abrasion and breakdown during transport, attributed to lithological properties (Dreimanis and Vagners, 1969; Haldorsen, 1981), appears as a likely factor to explain the difference in relative abundance between the softer dolostone and the more resistant quartz sandstone erratics. Levasseur and Prichonnet (1995) noted the smaller sizes of Albanel dolostone erratics compared with other lithologies of the Mistassini Group in the ChapaisChibougamau area. The distribution of the dolostones around the Pipmuacan Reservoir (44 out of 39500 clasts), located at a distance of $260 \mathrm{~km}$ from the source is, however, comparable to the distribution of dolostone clasts around the Gouin Reservoir (146 out of 149000 clasts) located at a distance of $170 \mathrm{~km}$ from the formation. The different distances from the source rocks for both reservoirs and the presence of two ice flows of different age and direction in Pipmuacan Reservoir preclude direct a comparison between the two sites. It is, however, of interest to note that the proportion of dolostone erratics in Pipmuacan Reservoir is comparable to that of Gouin Reservoir, even after the Pipmuacan Reservoir area had been subjected to the erosive action of ice flow 3, that could only have decrease the ratio dolostone clasts/sandstone clasts.

While it is probable that some of the destruction of dolostone clasts from the Albanel Formation took place by comminution during glacial transport, some of it can be attributed to chemical postglacial weathering. Throughout this survey, and at all locations where dolostone clasts occur at the surface, widespread evidence of chemical alteration was observed. In some areas, between $15-20 \%$ of dolostone clasts counted along beaches, were found to be at various stages of destruction or "decalcification" (Fig. 23). Deeply decalcified clasts are usually dark rusty brown, light-weight, and break into a powdery mass or along bedding planes, when struck with a hammer. Some clasts, when split open, show a rusty brown, porous envelope surrounding an intact, unweathered, inner core. All counted erratics were collected at the surface, very rarely below the solum. Weathered dolostone clasts, probably due to water percolating through the pervious granular deposits, were frequently observed in borrow pits and along shorelines carved in glaciofluvial deposits. These observations indicate that calcium carbonate was leached out of dolostone clasts, sub-aerially exposed since deglaciation or at least for prolonged periods. The weathering conditions just described for Mistassini dolostone erratics and the relative abundance of dolostone and sandstone clasts appear to differ from those observed by Dionne on similar erratics in the Tadoussac area and at other locations along the north shore of the St. Lawrence estuary (Dionne, personal communication, 2006). Dionne

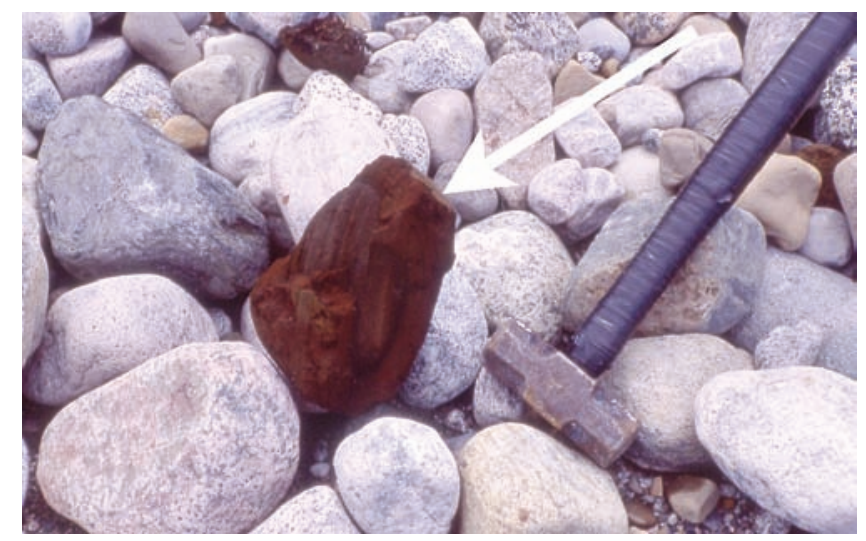

FIGURE 23. Deeply weathered, rusty brown, porous, decalcified, dolostone erratic (arrow) from the Albanel Formation.

Erratique de dolomie de la Formation d'Albanel à un stade avançé d'altération, de couleur rouille, poreux et décalcifié.

reports that dolostone clasts are generally well-preserved, and weathering when present, is usually weak and superficial. Weathered dolostones are usually buried in clay, indicating that the clasts were already weathered when released from the clay. He also noted that the dolostone clasts outnumber the sandstone/quartzite clasts. These discrepancies are probably related to different sedimentological environments. Dolostone erratics described by Dionne were eroded from or obtained directly from till or glaciofluvial sections along the shore, and as such were probably buried and protected from sub-aerial weathering since deposition, whereas all dolostone clasts counted in the present study, were obtained at the surface.

Thus, two different processes, comminution and sub-aerial weathering, may account for the marked differences in clast abundance between the dolostone and the sandstone erratics described in this report. Postglacial chemical weathering of surface dolostone erratics is probably the most important process that accounts for the differences. Hundreds of representative samples of Mistassini erratics, from coarse gravel to boulder size, were systematically collected from the 11 areas visited. Mineralogical analysis and detailed descriptions of weathered dolostone clasts will be provided in a separate study along with a clast abundance profile extending for several hundred $\mathrm{km}$ from the Papaskwasati Formation. In this paper, the discussion is limited to information providing a new insight into paleo- ice-flow directions for the central part of Grenville Province in Québec.

The long glacial transport distances associated with the former east-southeastward ice flow, in the large area east of Lake St-Jean (Fig. 7), are nearly comparable with those associated with the deglaciation flows in the western part of the study area. In the Baie-Comeau-Pipmuacan area, the late deglaciation flows are also toward the southeast and glacial transport from both flows may be cumulative. The cumulative effect on glacial transport of two or more ice movements in the same general direction is rarely discussed in the literature, probably because of the difficulty of estimating it. Strobel and Faure (1987), tracing Precambrian Shield indicator clasts 
in till, from a source in southern Ontario, to large ice-marginal moraines in Ohio and Indiana, U.S.A., found a nearly constant $4 \%$ value for more than $800 \mathrm{~km}$ down-ice, in the tail part of the dispersal train. This value is higher than reported here at shorter distances, and may be due to contrasting lithology, i.e. hard igneous clasts entrained in till, derived primarily from the softer carbonate rocks of the Great Lakes area vs softer dolostone clasts entrained in an abrasive, sandy till, derived from crystalline bedrock, in the present study. Alternatively it may be the result of cumulative transport. Strobel and Faure measured transport distances along flow lines that are representative of the last deglaciation flows only, in the Great Lakes region. These flow lines may, or may not coincide with those of earlier ice flows in the region. In most of Canada the orientations and directions of ice flows that preceded that of the last regional flow (or flows) remain poorly known, and the glacial lineation left by the last regional flow, as it appears on small scale maps like the Glacial map of Canada (Prest et al., 1968), is often the only evidence available to evaluate transport distances and directions.

\section{CONCLUSIONS}

The mapping of cross-striated outcrops and lithological indicators of glacial transport from the Proterozoic rocks of the Mistassini Group and the Otish Supergroup, within an area of about $230000 \mathrm{~km}^{2}$, north of the St. Lawrence River Valley indicate that at least three widespread, intersecting, glacial events, starting with a direction of ice movement toward the west-northwest, followed by a second one toward the southeast, and ice flows toward the southwest, south and southeast that formed during deglaciation, occurred in Wisconsinan time.

The extent and relative chronology of these ice flows are based on the strong correlation between the striation record established during the course of this survey, and from earlier work carried out during the last 20 years, within and in the vicinity of the study area, and on the dispersal of selected, distinctive, erratics from the Lake Mistassini and Otish basins.

The Chibougamau-Lake Mistassini area lies within a narrow zone a few kilometres wide, oriented NE-SW, extending from Caniapiscau Reservoir to the Abitibi region, within which evidence for the three major ice flows can be seen in both the striation record and glacial transport data. The zone marks the southern limit of striations indicative of the former northwestward ice flow, and the northern limit of those formed by the former southeastward ice flow.

The former northwestward ice flow results from an expanding glacier, of probable Early Wisconsinan age, initiated in the Québec highlands, due to the coalescence of local ice caps formed on the highest mountains, to the north of and parallel to the St. Lawrence River Valley, between the Laurentian region north of Montreal, and Labrador. This expansion appears compatible with the windward growth model proposed by Flint (1943). Flow direction was toward the southeast (south) on the south side of the divide.

The divide migrated to the northwest of Lake Mistassini in LGM time and shifted counterclockwise from its initial NE-SW orientation. This adjustment is required to explain the pres- ence of indicator clasts of the Chibougamau Formation of the Mistassini Group on the shore of Pipmuacan Reservoir, and sandstone clasts from the Otish Supergroup in the Manicouagan Reservoir area.

During deglaciation (10.8 ka to $8.0 \mathrm{ka}$; Occhietti et al., 2004: Fig. 4), the ice front shifted from a dominant NE-SW orientation to a dominant NW-SE orientation, south of Lake Mistassini, and to a dominant NNW-SSE orientation, northwest of Lake Mistassini. These adjustments, well-preserved in the striation record, account for the counterclockwise shift in ice flow observed within James Bay and to the east of it to the Chibougamau area (Veillette, 1995), and the clockwise shift in ice flow on Grenville Province described in this paper.

Counts of sandstone and dolostone erratics found at the surface, were compared by taking into account distance of travel and area of occurrence of the source rocks. The relative abundance of the two lithological indicators indicates that a higher proportion of dolostone erratics were destroyed by comminution during glacial transport or by chemical weathering in postglacial time, or by both processes.

This complex sequence of ice flows provides ground control and constraints for ice sheet reconstructions (Fisher et al., 1985; Clark et al., 1996; Dyke et al., 2002) and evolution of ice masses based on the analysis of intersecting glacial lineaments (Clark et al., 2000). Mineral exploration methods relying on the sampling of glacial sediments can benefit from a better understanding of ice flow chronology. Intensive diamond exploration is underway, north of the Grenville Front, within and in the vicinity of the zone that marks the southern limit of striations indicative of the former northwestward ice flow, and the northern limit of the former southeastward ice flow.

\section{ACKNOWLEDGEMENTS}

The able field assistance of Alexandre French, Theo Yates, Jean-Louis Lauriol, Robert Harrison, Michelle Labelle and Michèle Quenneville, was essential to this project given the heavy logistics involved. The participation of Arthur S. Dyke, Geological Survey of Canada, in two of the 11 areas visited, and his interest in the project were most helpful. Linda Dredge, Geological Survey of Canada, read an earlier version of the manuscript. Jean-Claude Dionne, Université Laval, reviewed the manuscript, offered helpful suggestions, provided samples from the Tadoussac area and, over the years, stimulating discussion on the distribution of Mistassini erratics. Reviewer Beth McClenaghan, Geological Survey of Canada, helped improve the manuscript. Victor K. Prest showed sustained interest in the distribution of the Mistassini erratics and discussed their significance in the evolution of the eastern part of the LIS. Hydro-Québec supplied hydrological data for some of the reservoirs visited, and Alcan Ltd gave access to the Manouane Reservoir and provided communication support while working on the reservoir. All reservoirs visited are not equipped with navigational aids, information provided by several individuals familiar with the area, helped insured safe navigation. The Université du Québec in Abitibi-Témiscamingue (UQAT) supported the project by providing technical support. Jean-Louis Caty from the Ministère des Ressources naturelles et de la Faune du Québec, supplied information on specific sites on 
the shoreline of Lake Mistassini. Richard Grieve and Anne Thériault from the Geological Survey of Canada, provided information and meltrock samples from the Manicouagan crater. Some field equipment was provided by the Geological Survey of Canada during the first three years of this 7-year project. Raymond Fournier, Geotech, provided graphics support. The support of editors Steven Wolfe and Alain Plouffe is appreciated. The assistance of organisations and individuals encountered in the field, who facilitated the realization of this project is greatly appreciated. Sincere thanks are extended to all.

\section{REFERENCES}

Agassiz, L., 1840. Études sur les glaciers, Neuchâtel, Jent et Gassmann. 346 p. Beaudry, L.M., 1994. Glacial dispersal from the Opemisca pluton in the Chapais area, central Québec, Thèse de doctorat, Université du Québec à Chicoutimi, Chapitre III : p. 135-184.

Bergeron, R., 1957. Late Precambrian Rocks of the North Shore of the St. Lawrence River and of the Mistassini and Otish Mountain Areas, Québec, p. 124-131. In J.E. Gill, ed., The Proterozoic in Canada. Royal Society of Canada, Special Publication 2, p. 124-131.

Bisson, L., 1987. Géologie des dépôts quaternaires du canton de Scott, Chibougamau, Québec, avec applications à la prospection minérale, Mémoire de maîtrise, Université du Québec à Montréal, $182 \mathrm{p}$.

Bouchard, M.A., Cadieux, B. and Goutier, F., 1984. L'origine et les caractéristiques des lithofaciès du till dans le secteur nord du lac Albanel, Québec : une étude de la dispersion glaciaire clastique. Canadian Institute of Mining and Metallurgy, Special volume 34 : 244-260.

Bouchard, M.A. and Martineau, G., 1985. Southeastward ice flow in central Québec and its paleogeographic significance. Canadian Journal of Earth Sciences, 22 : 1536-1541.

Boulton, G.S. and Clark, C.D.,1990. The Laurentide Ice Sheet through the last glacial cycle: the topology of drift lineations as a key to the dynamic behaviour of former ice sheets. Transactions of the Royal Society of Edinburgh: Earth Sciences, $81: 327-347$.

Boulton, G.S., Smith, G.D., Jones, A.S. and Newsome, J., 1985. Glacial geology and glaciology of the last mid-latitude ice sheets. Journal of the Geological Society of London, $142:$ 447-474.

Cadieux, B., 1986. La dispersion glaciaire des fragments de roche dans la région du lac Mistassini, Québec. Mémoire de maîtrise, Université de Montréal, $146 \mathrm{p}$.

Caty, J.-L., 1976. Stratigraphie et sédimentologie de la Formation de Papaskwasati, Thèse de doctorat, Université de Montréal, 220 p.

Chown, E.H., 1960. Région de la rivière Papaskwasati, territoire de Mistassini, Québec, Ministère des Richesses Naturelles du Québec, Rapport préliminaire 415, $11 \mathrm{p}$.

Chown, E.H. and Caty, J.-L., 1973. The clastic members of the Mistassini-Otish Basin, p. 49-71. In G.M. Young, ed., Huronian stratigraphy and sedimentation. Geological Association of Canada, Special Paper 12.

Clark, P.U., Licciardi, J.M., MacAyeal, D.R. and Jenson, J.W., 1996. Numerical reconstruction of a soft-bedded Laurentide Ice Sheet during the Last Glacial Maximum. Geology, 24 : 679-682.

Clark, C.D., Knight, J.K. and Gray, J.T., 2000. Geomorphological reconstruction of the Labrador Sector of the Laurentide Ice Sheet. Quaternary Science Reviews, $19: 1343-1366$.

Commission de toponymie du Québec, 1996. Noms et lieux du Québec, dic-

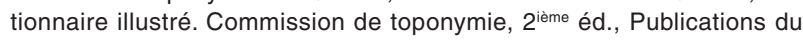
Québec, 925 p.

De Corta, H., 1988. Les dépôts quaternaires de la région lac Rohault-lac Boisvert (sud de Chibougamau); aspects de la dispersion glaciaire clastique, Mémoire de maîtrise, Université du Québec à Montréal, 112 p.

Dilabio, R.N.W., 1976. Glacial dispersal of rocks and minerals in the Lake Mistassini-Lake Waconichi area, Québec, with special reference to the Icon dispersal train. Ph.D. thesis, University of Western Ontario, $174 \mathrm{p}$.

Dionne, J.-C., 1973. La dispersion des cailloux ordoviciens dans les formations quaternaires au Saguenay/Lac-Saint-Jean, Québec. Revue de Géographie de Montréal, 27 : 339-364.
Dionne, J.-C., 1986. Blocs de dolomie à stromatolites sur les rives de l'estuaire du Saint-Laurent, Québec. Géographie physique et Quaternaire, 40 : 93-98.

Dionne, J.-C., 1994. Les erratiques lointains de l'embouchure du Saguenay, Québec. Géographie physique et Quaternaire, 48 : 174-179.

Dionne, J.-C. and Bernatchez, P., 2000. Les erratiques de dolomie sur le rivage des Escoumains, Côte Nord de l'estuaire maritime du Saint-Laurent, Québec. Atlantic Geology, 36 : 117-129.

Dionne, J.-C., 2001. Erratiques de dolomie au cap Colombier, sur la haute CôteNord du Saint-Laurent estuarien. Géographie physique et Quaternaire, 55 : 101-107.

Dyke, A.S. and Prest, V.K., 1987. Late Wisconsinan and Holocene history of the Laurentide Ice Sheet. Géographie physique et Quaternaire, $41: 237-263$.

Dyke, A.S., Andrews, J.T., Clark, P.U., England, J.H., Miller, G.H., Shaw, J. and Veillette, J.J. 2002. The Laurentide and Innuitian ice sheets during the Last Glacial Maximum. Quaternary Science Reviews, 21 : 9-31.

Dreimanis, A. and Vagners, U.J., 1969. Lithologic relation of till to bedrock, p. 93-98. In H.E. Wright Jr., ed., Quaternary Geology and climate. National Academy of Science, Washington D.C.

Fisher, D.A., Reeh, N. and Langley, K., 1985. Objective reconstructions of the Late Wisconsinan Laurentide Ice Sheet and the significance of deformable beds. Géographie physique et Quaternaire, $39: 229-238$.

Flint, R.F., 1943. Growth of the American Ice Sheet during the Wisconsin Age. Geological Society of America Bulletin, 54 : 325-362.

Flint, R.F., 1947. Glacial geology and the Pleistocene Epoch. John Wiley \& Sons, New York, $589 \mathrm{p}$.

Flint, R.F., 1971. Glacial and Quaternary Geology. John Wiley \& Sons, New York, $892 \mathrm{p}$.

Genest, S., 1989. Analyse du bassin d'Otish, Protérozoïque inférieur, Québec. Thèse de doctorat, Université de Montréal, $311 \mathrm{p}$.

Gillett, L.B., 1966. La géologie de la région du lac Assinica, territoire de l'Abitibi, Québec. Ministère des Richesses naturelles du Québec, Rapport préliminaire 550, Québec, 18 p.

Grieve, R.A.F. and Head, III, J.W., 1983. The Manicouagan Impact Structure: An Analysis of its Original Dimensions and Form. Proceedings of the Thirteenth Lunar and Planetary Science Conference, Part 2, Journal of Geophysical Research, 88, Supplement A807-A818, February $15^{\text {th }}, 1983$.

Govare, É., 1995. Paléoenvironnements de la région de Charlevoix, Québec. Thèse de doctorat, Université de Montréal, $429 \mathrm{p}$.

Haldorsen, S., 1981. Grain-size distribution of subglacial till and its relation to glacial crushing and abrasion. Boreas, $10: 91-105$.

Henderson, P.J., 1989. Provenance and depositional facies of surficial sediments in Hudson Bay, a glaciated epeiric sea. Ph.D thesis, University of Ottawa, $288 \mathrm{p}$.

Hirvas, H. and Nenonen, K., 1987. The till stratigraphy of Finland, p. 49-63, In R. Kujansu and M. Saarnisto, eds., INQUA Till Symposium, Finland 1985, Geological Survey of Finland, Special Paper 3.

Hofmann, H.J., 1978. New stromatolites from the Aphebian Mistassini Group, Québec. Canadian Journal of Earth Sciences, $15: 571-585$.

Ignatius, M.H., 1958. On the Late-Wisconsin deglaciation in Eastern Canada. Acta Geographica, 16, 34 p.

Jansson, K.N., Kleman, J. and Marchand, D., 2002. The succession of ice-flow patterns in north-central Québec, Canada. Quaternary Science Reviews, $21: 503-523$.

Kaszycki, C.A., 1989. Surficial geology and Till composition Northwestern Manitoba. Geological Survey of Canada, Ottawa, Open File 2118, 40 p.

Klassen, R.A and Thompson, F.J., 1993. Glacial history, drift composition, and mineral exploration, central Labrador. Geological Survey of Canada, Ottawa, Bulletin 435, $76 \mathrm{p}$.

Krumbein, W.C., 1937. Sediments and exponential curves. Journal of Geology, $45: 577-601$.

Levasseur, D. and Prichonnet, G., 1995. La dispersion clastique des débris rocheux dans les eskers et le till adjacent de la région de ChapaisChibougamau (Québec) au Wisconsinien supérieur. Canadian Journal of Earth Sciences, 32 : 590-602.

Long, D.G.F., 1973. The Stratigraphy and Sedimentology of the Chibougamau Formation. Ph.D. thesis, University of Western Ontario, $305 \mathrm{p}$.

Low, A.P., 1886. On the Mistassini expedition 1884-1885. Geological Survey of Canada, Ottawa, Annual Report D, p. 5-36. 
Low, A.P., 1889. Report on exploration in James Bay, and country east of Hudson Bay, drained by the Big Great Whale and Clearwater Rivers, 1887-1888. Geological and Natural History Survey of Canada, Ottawa, Annual Report 3, Part II, Report J, 62 p.

Low, A.P., 1903. On an exploration of the east coast of Hudson Bay from Cape Wolstenholme to the south end of James Bay. Geological Survey of Canada, Ottawa, Annual Report D, 13, p. 5-82.

Martineau, G., 1984. Géologie du Quaternaire de la région de Chibougamau. Ministère de l'Énergie et des Ressources du Québec. ET 83-20, 15 p.

Martineau, G., Bouchard, M.A. and Prichonnet, G., 1984. Southeastward ice flows in central Québec and its implications for the location of the Laurentide Ice Sheet dispersal centres. Geological Association of Canada, Abstracts with Programs, 1984.

McMartin, I. and Henderson, P.J., 2004. Evidence from Keewatin (central Nunavut) for paleo-ice divide migration. Géographie physique et Quaternaire, $58: 163-186$.

Ministère de l'Énergie et des Ressources du Québec, 1987. Le Québec en relief. Elevation map of Québec and Labrador with parts of eastern Ontario, Newfoundland, Nova Scotia and Prince-Edward Island. Ministère de l'Énergie et des Resources du Québec, Service de la cartographie, 1:2 000000 scale.

Murtaugh, J.G., 1976. Manicouagan Impact Structure. Ministère des Richesses naturelles, Direction générale des Mines, DPV-432, 180 p.

Murphy, D.L., 1966. Région des lacs Frotet et Troilus, Territoire de l'Abitibi, Québec. Ministère des Richesses Naturelles du Québec, Rapport géologique 123, $40 \mathrm{p}$.

Mutanen, T., 1971. An example of the use of boulder counting in lithologic mapping. Bulletin of the Geological Society of Finland, $43: 131-140$.

National Atlas of Canada, 1973. Relief map of Canada, Map MRC 1111F, Energy Mines and Resources and Environment Canada, Ottawa, Canada.

National Atlas of Canada, 1991. Canada Precipitation, Map MRC 4145, Canada Snowfall Map, MRC 4126 ( $5^{\text {th }}$ ed.), Energy Mines and Resources Canada, Ottawa, Canada.

Occhietti, S., 1982. Synthèse lithostratigraphique et paléoenvironnements du Quaternaire du Québec méridional. Hypothèse d'un centre d'englacement wisconsinien au Nouveau-Québec. Géographie physique et Quaternaire, $36: 15-39$.

Occhietti, S., Parent, M., Shilts, W.W., Dionne, J.-C., Govare, E. and Harmand D., 2001. Late Wisconsinan glacial dynamics, deglaciation and marine invasion in southern Québec, Geological Society of America, Special Paper 351, p. 245-272.

Occhietti, S., Govare, E., Klassen, R., Parent, M. and Vincent, J.-S., 2004. Late Wisconsinan - Early Holocene deglaciation of Québec-Labrador, p. 243-273. In J. Ehlers and P.L. Gibbard, eds., Quaternary Glaciations Extent and Chronology, Part II: North America. Elsevier, New York, 440 p.

Paradis, S.J., 2003a. Géologie des formations en surface, Lac La Trêve, Municipalité de la baie James, Québec, Map 2061A, 1:100 000.

Paradis, S.J., 2003b. Géologie des formations en surface, Lac Chibougamau, Municipalité de Chibougamau, Québec, Map 2062A, 1:100 000.

Paradis, S.J., 2003c. Géologie des formations en surface, Lac Caopatina, Municipalité de la baie James, Québec, Map 2063A, 1:100 000.

Paradis, S.J., 2003d. Géologie des formations en surface, Lac Father, Municipalité de la baie James, Québec, Map 2064A, 1:100 000.

Paradis, S.J. and Boisvert, E., 1995. Séquence des écoulements glaciaires dans le secteur de Chibougamau-Némiscau, Québec. Current Research, Geological Survey of Canada, Ottawa, Paper 1995-C, p. 259-264.

Parent, M., Paradis, S.J.and Boisvert, E.,1995. Ice-flow patterns and glacial transport in the eastern Hudson Bay region: implications for the Late Quaternary dynamics of the Laurentide Ice Sheet. Canadian Journal of Earth Sciences, 32 : 2057-2070.

Parent, M., Paradis, S.J. and Doiron, A., 1996. Palimpsest glacial dispersal trains and their significance for drift prospecting. Journal of Geochemical Exploration, 56 : 123-140.

Prest, V.K., Grant, R.R. and Rampton, V.N., 1968. Glacial Map of Canada. Geological Survey of Canada, Ottawa, Map 1253A, scale 1:5000 000.

Prest, V.K. and Nielsen, E., 1987. The Laurentide Ice Sheet and long-distance transport. Geological Survey of Finland, Special Paper 3, p. 91-101.

Prichonnet, G. and Beaudry, L.M., 1990. Évidences d'un écoulement glaciaire sud, antérieur à l'écoulement sud-ouest du Wisconsinien supérieur, région de Chapais. Current Research, Part C, Geological Survey of Canada, Ottawa, Paper 90-1C, p. 331-338.
Prichonnet, G. Martineau, G. and Bisson, L., 1984. Les dépôts quaternaires de la région de Chibougamau, Québec. Géographie physique et Quaternaire, 38 : 287-304.

Puranen, R., 1988. Modelling of glacial transport of basal tills in Finland. Geological Survey of Finland, Report of investigation 81, 36 p.

Ressources Naturelles du Québec, 2002. Carte géologique du Québec, DV 2002-06, 1:2000 000 scale.

Roy, M., 1998. Pleistocene stratigraphy of the lower Nelson River areaImplications for the evolution of the Hudson Bay Lowland, Manitoba, Canada, 220 p.

Sagan, C., 1996. The Demon-Haunted World, Science as a candle in the dark, Chapter 12, The fine art of Baloney detection, Random House, New York, $476 \mathrm{p}$.

Salonen, V.-P., 1986. Glacial transport distance distribution of surface boulders in Finland. Geological Survey of Finland, Bulletin 338, 57 p.

Sauramo, M., 1929. The Quaternary Geology of Finland. Bulletin de la Commission géologique de Finlande, 86, $110 \mathrm{p}$.

Shilts, W.W., 1976. Glacial till and mineral exploration, p. 205-224, In R.F. Legget, ed., Glacial till. Royal Society of Canada, Special Publication 12.

Strobel, M.L. and Faure, G., 1987. Transport of indicator clasts by ice sheets and the transport half-distance: a contribution to prospecting for ore deposits. Journal of Geology, 95 : 687-697.

Thorleifson, L.H., Wyatt, P.H., Shilts, W.W. and Neilsen, E., 1992. Hudson Bay Lowland stratigraphy: Evidence for early Wisconsinan glaciation centreed in Québec, In P.U. Clark and P.D. Lea, eds., The Last Interglacial-Glacial Transition in North America: Boulder, Colorado. Geological Society of America, Special Paper 270.

Thorleifson, L.H., Wyatt, P.H. and Warman, T.A., 1993. Quaternary stratigraphy of the Severn and Winisk drainage basins, northern Ontario. Geological Survey of Canada, Ottawa, Bulletin 442, $59 \mathrm{p}$.

Upham, W., 1895. Discrimination of glacial accumulation and invasion. Geological Society of America Bulletin, $6: 343-352$.

Veillette, J.J., 1986. Former southwesterly ice flows in Abitibi-Témiscamingue: implications for the configuration of the Late Wisconsinan Ice Sheet. Canadian Journal of Earth Sciences, 23 : 1724-1741.

Veillette, J.J., 1995. New evidence for northwestward glacial ice flow, James Bay region, Québec. Current Research, Geological Survey of Canada, Ottawa, 1995-C, p. 249-258.

Veillette, J.J., 1996. Géomorphologie et géologie du quaternaire du Témiscamingue, Québec et Ontario. Commission géologique du Canada, Ottawa, Bulletin 476, 269 p.

Veillette, J.J., 1997. Le rôle d'un courant de glace tardif dans la déglaciation de la baie James. Géographie physique et Quaternaire, 51 : 141-161.

Veillette, J.J., Paradis, S.J., Thibaudeau, P. and Pomares, J.-S., 1991. Distribution of distinctive Hudson Bay erratics and the problem of the Cochrane limit in Abitibi, Québec. Current Research, Part C, Geological Survey of Canada, Ottawa, Paper 91-1C, p. 135-142.

Veillette, J.J. and Pomares, J.-S., 1991. Older ice flows in the Matagami-Chapais area, Québec. Current Research, Part C, Geological Survey of Canada, Ottawa, Paper 91-1C, p. 143-148.

Veillette, J.J. and Roy, M. 1995. The spectacular cross-striated outcrops of James Bay, Québec. Current Research, Geological Survey of Canada, Ottawa, 1995-C, p. 243-248.

Veillette, J.J. and McClenaghan, M.B., 1996. Sequence of glacial ice flows in Abitibi-Timiskaming; implications for mineral exploration and dispersal of calcareous rocks from the Hudson Bay basin, Québec and Ontario. Geological Survey of Canada, Ottawa, Open File 3033, Map 1:500 000 scale.

Veillette, J.J., Dyke, A.S. and Roy, M., 1999. Ice-flow evolution of the Labrador Sector of the Laurentide Ice Sheet: a review, with new evidence from northern Québec. Quaternary Science Reviews, 18 : 993-1019.

Veillette, J.J., Paradis, S.J. and Thibaudeau, P., 2003. Les cartes de formations en surface de l'Abitibi, Québec. Geological Survey of Canada, Ottawa, Open File 1523, 10 maps, 1:100 000 scale.

Young, G.M., 1970. An extensive Early Proterozoic glaciation in North America? Paleogeography, Paleoclimatology, Paleoecology, 7 : 85-101. 